ARTICLE

https://doi.org/10.1038/s41467-019-13792-0

\title{
Ocean Carbon Storage across the middle Miocene: a new interpretation for the Monterey Event
}

\author{
S.M. Sosdian (1) ${ }^{1 \star}$, T.L. Babila (1) ${ }^{2}$, R. Greenop ${ }^{3}$, G.L. Foster ${ }^{2} \&$ C.H. Lear ${ }^{1}$
}

The Miocene Climatic Optimum (MCO, 14-17 Ma) was $\sim 3-4{ }^{\circ} \mathrm{C}$ warmer than present, similar to estimates for 2100. Coincident with the $\mathrm{MCO}$ is the Monterey positive carbon isotope $\left(\delta^{13} \mathrm{C}\right)$ excursion, with oceans more depleted in ${ }^{12} \mathrm{C}$ relative to ${ }^{13} \mathrm{C}$ than any time in the past 50 Myrs. The long-standing Monterey Hypothesis uses this excursion to invoke massive marine organic carbon burial and draw-down of atmospheric $\mathrm{CO}_{2}$ as a cause for the subsequent Miocene Climate Transition and Antarctic glaciation. However, this hypothesis cannot explain the multi-Myr lag between the $\delta^{13} \mathrm{C}$ excursion and global cooling. We use planktic foraminiferal $\mathrm{B} / \mathrm{Ca}, \delta^{11} \mathrm{~B}, \delta^{13} \mathrm{C}$, and $\mathrm{Mg} / \mathrm{Ca}$ to reconstruct surface ocean carbonate chemistry and temperature. We propose that the MCO was associated with elevated oceanic dissolved inorganic carbon caused by volcanic degassing, global warming, and sea-level rise. A key negative feedback of this warm climate was the organic carbon burial on drowned continental shelves.

\footnotetext{
${ }^{1}$ Cardiff University School of Earth and Ocean Sciences, Cardiff CF10 3AT, UK. ${ }^{2}$ National Oceanography Centre Southampton, School of Ocean and Earth Science, University of Southampton, Waterfront Campus, Southampton SO14 3ZA, UK. ${ }^{3}$ School of Earth and Environmental Science, University of St. Andrews, St. Andrews KY16 9AL, UK. *email: SosdianS@cardiff.ac.uk
} 
U nderstanding the causes of natural variations in atmospheric $\mathrm{CO}_{2}$ concentration requires an appreciation of the temporal distribution of carbon among the major reservoirs involved in carbon exchange on geological timescales. On long timescales, $\mathrm{CO}_{2}$ is added to the atmosphere via volcanic degassing, metamorphic decarbonation, and oxidation of organic matter, and is removed via chemical weathering and organic carbon burial ${ }^{1,2}$. The primary mechanisms that set this delicate balance of carbon inputs and outputs, which ultimately regulates long-term climate, are strongly debated ${ }^{2-5}$. Silicate weathering and organic carbon burial are proposed as key feedbacks in setting and/or mediating Neogene atmospheric $\mathrm{CO}_{2}$ levels $s^{3,6,7}$. Beyond understanding the geochemical carbon cycle, constraining the outcome of anthropogenic carbon addition requires an understanding of not only climate and ecological sensitivity to rapid carbon evasion ${ }^{8,9}$, but also the nature of different carbon cycle feedbacks. This latter requirement arises, because carbon cycle feedbacks can either enhance atmospheric $\mathrm{CO}_{2}$ trends or play a crucial part in their recovery. Numerous studies of Pleistocene climate records identified several carbon cycle feedback processes that operate or are enhanced when the Earth is in colder than modern climate modes ${ }^{10,11}$. In contrast, the feedback processes that operated during past warm climates are less wellstudied and hence remain poorly understood, despite these being arguably more relevant for our warmer future. Carbon-cycle feedbacks are therefore currently not well represented in Earth System models and highlight a gap in our ability to predict future climate change $\mathrm{e}^{12,13}$.

An ideal time interval to explore the controls on long-term atmospheric $\mathrm{CO}_{2}$ and pinpoint such carbon cycle feedbacks is the Miocene Climatic Optimum (MCO) - a period of sustained global warmth $\sim 3{ }^{\circ} \mathrm{C}$ warmer than modern with reduced continental ice volume occurring ca. 14.7-17.0 Myrs ago and sitting within the Monterey carbon isotope excursion (MCIE) ${ }^{14,15}$. The MCIE was a prolonged $(\sim 3.5 \mathrm{Myrs}) \sim 1.0 \%$ positive carbon isotope excursion $\left(\delta^{13} \mathrm{C}\right)$ of the global oceans, documented in planktic and benthic foraminifera records centered on $\sim 15 \mathrm{Ma}^{16,17}$ (Fig. 1), contemporaneous with basin-wide deposition of organicrich deposits, as evident in the California Monterey Formation and elsewhere in the circum-Pacific Ocean ${ }^{16,18,19}$. The MCIE is usually described as comprising six carbon isotope maxima (CM events), which are paced by the $\sim 400 \mathrm{kyr}$ long-eccentricity cycle $^{17,20}$ (Fig. 1b, c). Following the MCO, the middle Miocene Climate Transition (MMCT)ushered in a cooler and apparently more stable icehouse climate mode in a series of cooling or ice growth steps, as evidenced by benthic oxygen isotope records ${ }^{17,21}$ (Fig. 1a) and a transition from a wet-based to dry-based Antarctic ice sheet ${ }^{22}$. This climate transition was associated with an overall decrease in the carbon isotopic composition of the ocean, although individual cooling steps have been associated with carbon maxima events, suggestive of the operation of positive carbon-cycle climate feedbacks ${ }^{23}$.

The classic interpretation, known as the Monterey Hypothesis ${ }^{19}$, proposed that long-term cooling increased the latitudinal gradient, invigorating upwelling, which led to increased organic carbon burial rates, lowering atmospheric $\mathrm{CO}_{2}$. This reinforced the initial cooling, while also increasing mean ocean $\delta^{13} \mathrm{C}$ composition and acting as a positive carbon cycle feedback. Subsequent hypotheses using strontium and osmium isotope records, invoked increased silicate weathering and enhanced nutrient delivery as a mechanism for $\mathrm{CO}_{2}$ draw down via enhanced organic carbon deposition and midMiocene cooling 6 . Others proposed the addition of volcanic $\mathrm{CO}_{2}$ emissions as a mechanism to maintain the MCO warmth ${ }^{24,25}$ and thereby stimulating high rates of chemical weathering alongside enhanced organic carbon burial. With the availability of the first continuous Miocene atmospheric $\mathrm{CO}_{2}$ records ${ }^{26}$ and identification

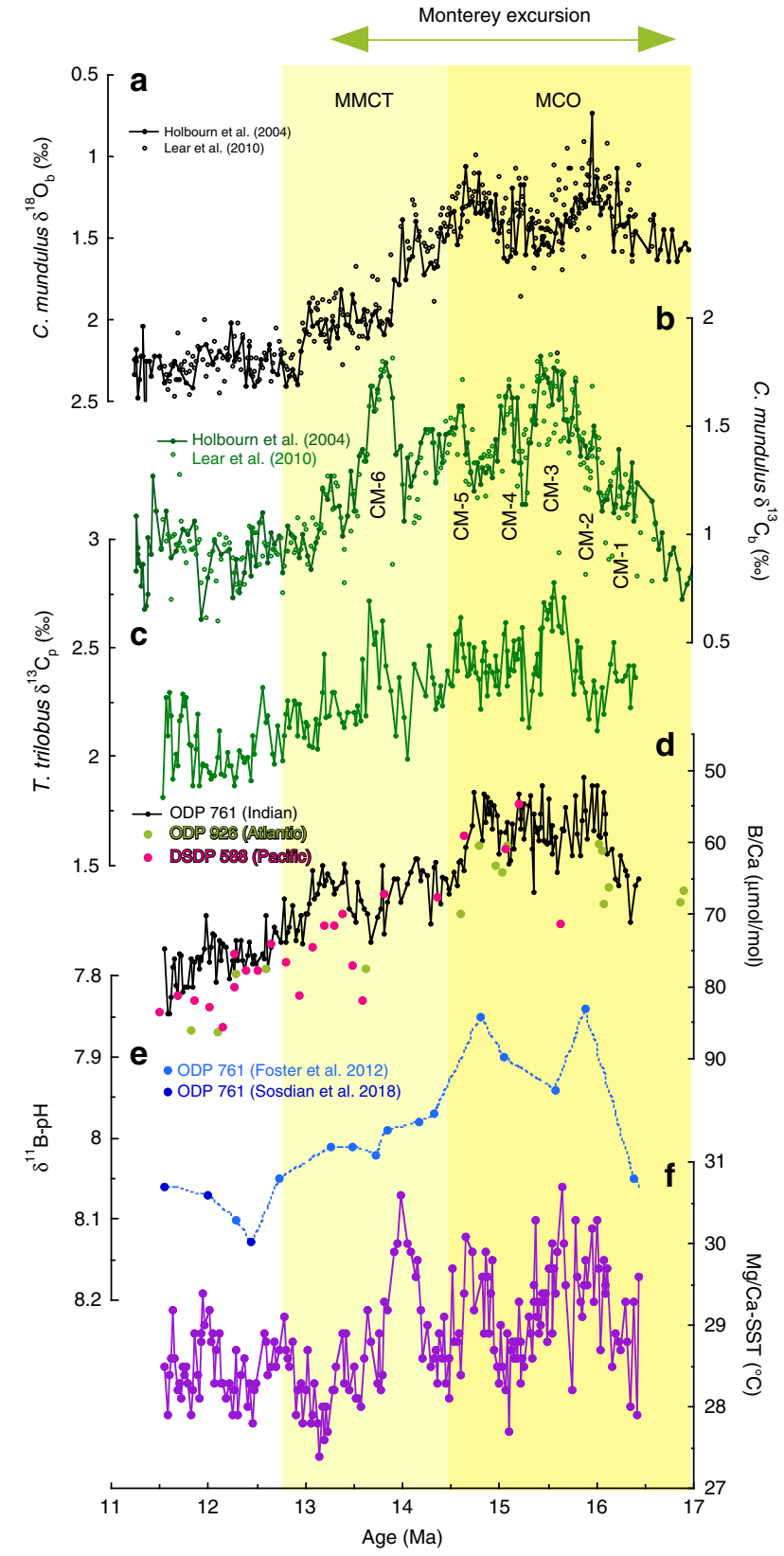

Fig. 1 Isotopic and trace metal records across the middle Miocene.

Previously published benthic foraminiferal (a) C. mundulus $\delta^{18} \mathrm{O}^{14,21}$ and (b) $\delta^{13} \mathrm{C}$ records from site ODP 761; (c) ODP $761 \mathrm{~T}$. trilobus $\delta^{13} \mathrm{C}$ record from this study; (d) ODP 761 (Indian), DSDP 588 (Pacific), and ODP 926 (Atlantic) T. trilobus $\mathrm{B} / \mathrm{Ca} \mu \mathrm{mol} / \mathrm{mol}$, and (e) T. trilobus $\delta^{11} \mathrm{~B}-\mathrm{pH}$ estimates ${ }^{29,35}$ from site 761 for one $\delta^{11} B_{\text {sw }}$ scenario 35,66 (G17) with Monte Carlo uncertainty estimates $(66 \% \mathrm{Cl})$; (f) SST estimates derived from $T$. trilobus $\mathrm{Mg} / \mathrm{Ca}$ at site 761 . Yellow vertical bars highlight the timing of the Miocene Climatic Optimum (MCO) and Middle Miocene Climate Transition (MMCT). Carbon isotope maxima (CM) events 1-6 are highlighted. Monterey carbon isotope excursion duration is highlighted by the above arrow.

of a minimum in $\mathrm{CO}_{2}$ concentrations during the $\mathrm{MCO}$, it was hypothesized that the positive $\delta^{13} \mathrm{C}$ anomaly were caused by increased rates of organic carbon burial ${ }^{19,26}$ with the warmth of the MCO sustained by its particular oceanographic configuration and low continental ice volume rather than by greenhouse gas forcing ${ }^{26}$. However, these interpretations relied on limited and, in some cases, unreliable, available indices of middle Miocene atmospheric $\mathrm{CO}_{2}$, 
silicate/organic carbon weathering, and climate variability ${ }^{6,19,24-27}$. In particular, the early alkenone-based $\mathrm{CO}_{2}$ reconstructions were biased by diagenetic imprints on the original paleotemperature records ${ }^{28}$ that were used to calculate $\mathrm{CO}_{2}$.

Recent efforts to reconstruct $\mathrm{CO}_{2}$ using the boron isotope and alkenone-based paleobarometers, with more robust organic proxy-based temperature estimates, instead suggest that the warmth of the MCO was sustained by relatively high $\mathrm{CO}_{2}$ (470-630 ppm) and the MMCT was associated with falling $\mathrm{CO}_{2}$ concentrations ${ }^{29-33}$. It is now thought that $\mathrm{CO}_{2}$ emissions associated with the Columbia River Flood Basalts (CRB) may have been at least in part responsible for the elevated $\mathrm{CO}_{2}$ during the climatic optimum $24,29,31,32$. Furthermore, geochemical box modeling suggests that increased concentrations of $\mathrm{CO}_{2}$ may also account for part of the MCIE itself, by increasing the photosynthetic isotopic fraction of carbon to form organic matter more enriched in ${ }^{12} \mathrm{C}$ on a global scale ${ }^{25}$. However, attributing the MCIE solely to a volcanic carbon source does not explain the $\sim 400 \mathrm{kyr}$ pacing of the carbon maxima events or the organic-rich sedimentation typified by the Monterey Formation and modeling produces a $\sim 0.4 \%$ o change in mean whole ocean $\delta^{13} \mathrm{C}$, whereas the MCIE itself has a far greater amplitude $(\sim 1 \%)^{25}$.

The association of the warmth of the MCO with elevated $\mathrm{CO}_{2}$ levels, organic-rich sedimentation, and positive carbon isotope excursions is reminiscent of the Cretaceous carbon cycle perturbations marked by widespread deposition of organic-rich sediments. This is thought to represent a key negative feedback in Earth's ice-free greenhouse climate mode, helping to draw-down atmospheric $\mathrm{CO}_{2}$, but is one which came at a cost to Cretaceous marine ecosystems-widespread oceanic anoxia ${ }^{33}$. Although similar in many respects, the Miocene intervals of organic-rich sedimentation were never associated with widespread anoxia ${ }^{34}$. Records of ocean carbon chemistry are therefore required to understand the nature of the carbon cycle feedbacks in this warmer-than-present icehouse world.

Although the development of the boron isotope $\left(\delta^{11} \mathrm{~B}\right)$ proxy has contributed to the recognition that climate and $\mathrm{CO}_{2}$ were coupled across the MCO and the MMCT $23,29,30,35, \mathrm{pH}$ is just one aspect of the ocean carbonate system. Directly reconstructing relative changes in dissolved inorganic carbon (DIC) content of seawater would allow us to more firmly quantify changes in oceanic carbon storage, which would enable the carbon cycle feedback processes associated with the MCO to be investigated.

Here we use planktic foraminiferal boron to calcium $(\mathrm{B} / \mathrm{Ca})$ ratios along with complementary published $\delta^{11} \mathrm{~B}$ records to reconstruct shifts in the concentration of $\left[\mathrm{B}(\mathrm{OH})_{4}{ }^{-} / \mathrm{DIC}\right]$ and $[\mathrm{B}$ $\left.(\mathrm{OH})_{4}{ }^{-} / \mathrm{HCO}_{3}{ }^{-}\right]$and relative changes in surface ocean DIC across the early Miocene, MCO, and MMCT. We present a moderately high resolution (one sample every $\sim 23 \mathrm{kyr}$ ) multiproxy record of $\mathrm{B} / \mathrm{Ca}, \mathrm{Mg} / \mathrm{Ca}$, and carbon isotope $\left(\delta^{13} \mathrm{C}_{\mathrm{p}}\right)$ variability in the planktic foraminifer Trilobatus trilobus spanning 16.5 to $11.5 \mathrm{Ma}$ from Ocean Drilling Program (ODP) Site 761 located in the tropical eastern Indian Ocean. We supplement this record with lower resolution $T$. trilobus $\mathrm{B} / \mathrm{Ca}$ reconstructions from the Pacific (Deep Sea Drilling Program (DSDP) Site 588; ODP Site 872) and Atlantic Ocean basins (ODP Site 926). We then apply ad hoc calibrations, based on modern culture and core-top datasets, along with existing records of $\mathrm{pH}$ to approximate shifts in surface ocean $\left[\mathrm{B}(\mathrm{OH})_{4}^{-} / \mathrm{DIC}\right]$ and $\left[\mathrm{B}(\mathrm{OH})_{4}{ }^{-}\right.$/ $\mathrm{HCO}_{3}{ }^{-}$], and ultimately DIC (see Methods). We then pair these records of ocean carbon storage with planktic $\mathrm{Mg} / \mathrm{Ca}$ and $\delta^{13} \mathrm{C}_{\mathrm{p}}$ records and previously published benthic $\delta^{18} \mathrm{O}$ records to provide a novel perspective on the MCIE and drivers of the carbon cycle across the middle Miocene. Our records show a positive relationship between DIC and the broad Monterey $\delta^{13} \mathrm{C}$ excursion, but a negative relationship between DIC and $\delta^{13} \mathrm{C}$ for the individual CM events. This suggests that the MCIE is not the sum of the carbon maxima events as originally supposed by the Monterey Hypothesis and instead that these two features of the carbon isotope record reflect different carbon cycle processes. We suggest that the broad MCIE represents a negative feedback process akin to Cretaceous Oceanic Anoxic Events (OAEs), which operated in a warmer-than-present icehouse world while the positive carbon isotope excursions (CM events) within the Monterey carbon excursion likely reflect a positive carbon cycle feedback process associated with orbital scale variability in marine productivity.

\section{Results}

B/Ca record of $\boldsymbol{T}$. trilobus from the mid-Miocene. ODP Site 761 T. trilobus $\mathrm{B} / \mathrm{Ca}, \mathrm{Mg} / \mathrm{Ca}$, and $\delta^{13} \mathrm{C}_{\mathrm{p}}$ records span a 5 -million-year time slice beginning from the onset of the $\mathrm{MCO}$, through its main body and into the MMCT (Fig. 1). At the onset of the MCIE, the planktic $\delta^{13} \mathrm{C}_{\mathrm{p}}$ record from Site 761 shows an overall increase, following the benthic $\delta^{13} \mathrm{C}$ record, with average MCO $\delta^{13} \mathrm{C}_{\mathrm{p}}$ values of $2.5 \%$ o decreasing to $\sim 2.0 \%$ by $12 \mathrm{Ma}$ (Fig. 1 ). Superimposed upon this background, long-term trend are the globally recognized $\mathrm{CM}$ events ${ }^{14}$ associated with glacial events and positive shifts in $\delta^{18} \mathrm{O}_{\mathrm{b}}$ during the middle Miocene.

During the onset of the MCO, T. trilobus $\mathrm{B} / \mathrm{Ca}$ ratios decreases from $\sim 70 \mu \mathrm{mol} / \mathrm{mol}$ to a minimum of $59 \pm 1 \mu \mathrm{mol} / \mathrm{mol}( \pm 2 \mathrm{SE}$; 14.7 to $16.0 \mathrm{Ma}$ ). This decrease in $\mathrm{B} / \mathrm{Ca}$ ratios is associated with increasing tropical Indian Ocean temperatures by $\sim 1.8^{\circ} \mathrm{C}$ (Fig. 1). Over the course of the middle Miocene, T. trilobus B/Ca increases across the MMCT from the minimum values of the MCO to a maximum $\mathrm{B} / \mathrm{Ca}$ value of $76 \pm 1 \mu \mathrm{mol} / \mathrm{mol}( \pm 2 \mathrm{SE}$; $13.5-11.5 \mathrm{Ma})$, an average increase of $17 \mu \mathrm{mol} / \mathrm{mol}$. This long-term increase in $\mathrm{B} /$ $\mathrm{Ca}$ records occurs in tandem with a small long-term temperature decrease of $\sim 0.7^{\circ} \mathrm{C}$. The long-term increase in $\mathrm{B} / \mathrm{Ca}$ values through the MMCT bears a remarkable similarity to the benthic $\delta^{18} \mathrm{O}\left(\delta^{18} \mathrm{O}_{\mathrm{b}}\right)$ records and is expressed in two steps with the first $\mathrm{B} / \mathrm{Ca}$ increase occurring at $14.7 \mathrm{Ma}$, with $\mathrm{B} / \mathrm{Ca}$ values reaching $66 \pm 1( \pm 2 \mathrm{SE}) \mu \mathrm{mol} / \mathrm{mol}$, before the final increase at $13 \mathrm{Ma}$ to $\sim 76 \mu \mathrm{mol} / \mathrm{mol}$.

Superimposed on this long-term B/Ca increase are numerous short-term variations in $\mathrm{B} / \mathrm{Ca}$ with an amplitude between 10 and $15 \mu \mathrm{mol} / \mathrm{mol}$. Earlier CM events show smaller scale peaks in $\mathrm{B} / \mathrm{Ca}$ corresponding to the peak foraminiferal $\delta^{13} \mathrm{C}$ values. Peak positive planktic and benthic $\delta^{13} \mathrm{C}$ values during CM6 correspond to an increase $\mathrm{B} / \mathrm{Ca}$ by $\sim 10 \mu \mathrm{mol} / \mathrm{mol}$. Further, the minimal longterm cooling in sea surface temperatures (SST) is punctuated by a sharp $2.4^{\circ} \mathrm{C}$ cooling from 14.0 to $13.8 \mathrm{Ma}$, associated with the positive $\delta^{18} \mathrm{O}_{\mathrm{b}}$ excursion and CM-6 event (Figs. 1 and 2). The overall SST amplitude at ODP 761 between warm, deglaciated and cool, glaciated conditions ranges from $3{ }^{\circ} \mathrm{C}$ to $2{ }^{\circ} \mathrm{C}$, with a minimum temperature around 13.2 Ma.

We also present lower resolution $T$. trilobus $\mathrm{B} / \mathrm{Ca}$ records from the Pacific (DSDP Site 588; ODP Site 872) and Atlantic (ODP Site 926) Ocean (Fig. 1 and Supplementary Figs. 1 and 2). These records show similarities in their general trends and absolute values to ODP Site 761, despite their different site locations, paleo water depths, and sediment burial depths. DSDP Site $588 \mathrm{~B} / \mathrm{Ca}$ increases from $62 \pm 4 \mu \mathrm{mol} / \mathrm{mol}( \pm 2 \mathrm{SE})$ during the MCO to $80 \pm$ $1 \mu \mathrm{mol} / \mathrm{mol}( \pm 2 \mathrm{SE})$, whereas ODP 926 increases from $65 \pm 1$ $\mu \mathrm{mol} / \mathrm{mol}( \pm 2 \mathrm{SE}$ ) during the MCO to $81 \pm 2 \mu \mathrm{mol} / \mathrm{mol}$ ( $\pm 2 \mathrm{SE}$ ). This corresponds to a long-term increase in $\mathrm{B} / \mathrm{Ca}$ of 18 and 16 $\mu \mathrm{mol} / \mathrm{mol}$ in the Pacific and Atlantic, respectively, similar to Indian Ocean. ODP $872 \mathrm{~B} / \mathrm{Ca}$ values decrease from the early Miocene into the MCO similar to the orbital-scale record from ODP 761, although our ODP 872 record is of lower resolution (Supplementary Fig. 2). 


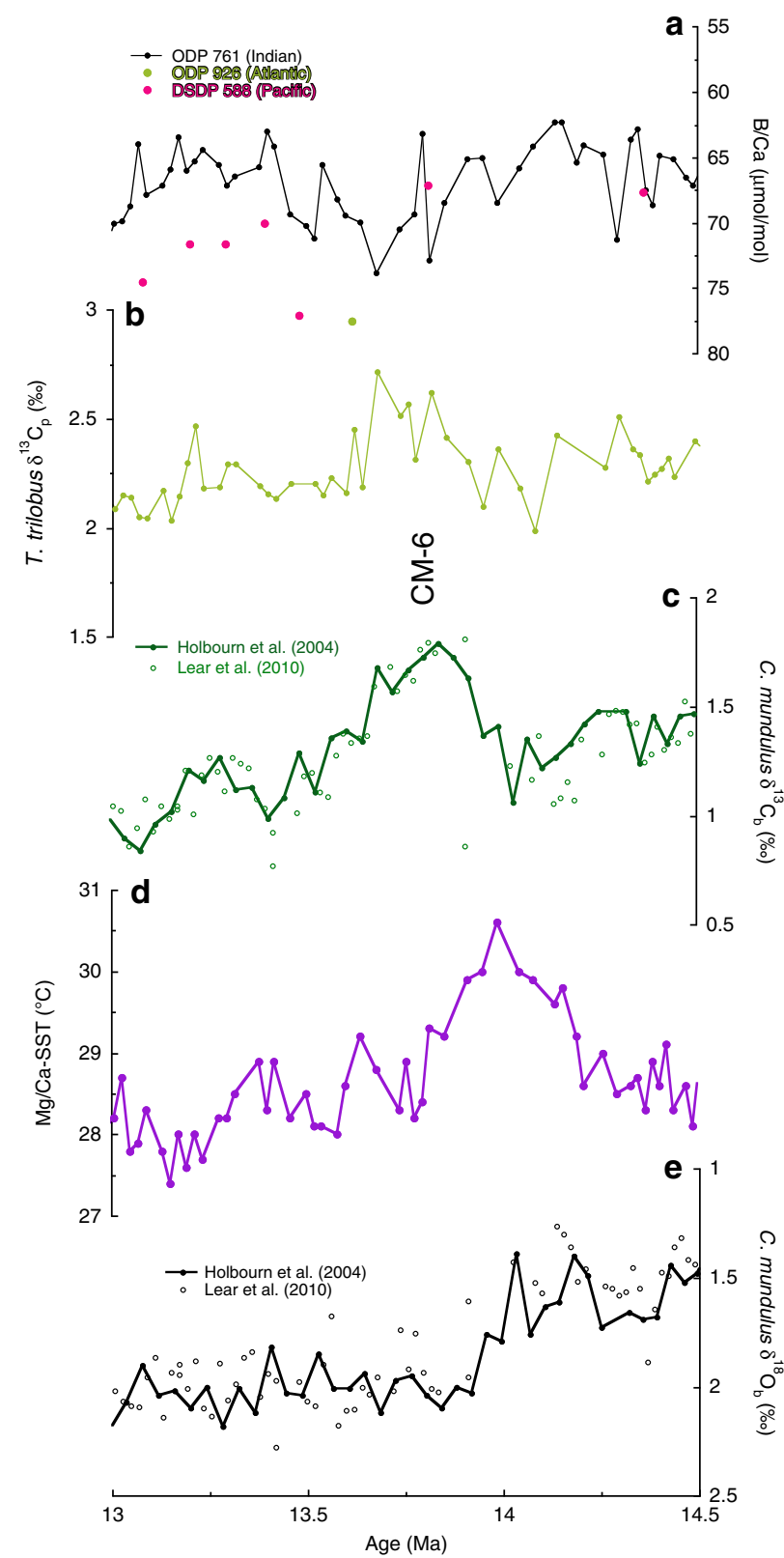

Fig. 2 Isotopic and trace metal records across CM6. a Planktic foraminifera T. trilobus B/Ca from Indian (ODP 761), Pacific (DSDP 588), and Atlantic Oceans (ODP 926 alongside (b) planktic foraminiferal carbon isotope record from ODP site 761. c Benthic foraminiferal carbon isotopes from ODP site 76144,21. d Mg/Ca-SST estimates from ODP site 761. e Benthic foraminiferal oxygen isotopes from ODP site $761^{14,21}$.

Overall, T. trilobus $\mathrm{B} / \mathrm{Ca}$ records document a substantial decrease at the start of the MCIE, followed by an increase from the MCO through the MMCT in the Indian, Pacific, and Atlantic oceans. The similar trend and magnitude revealed by these $\mathrm{B} / \mathrm{Ca}$ records, despite their diverse oceanographic settings suggests a global driver as the primary cause. In addition, the Site 761, Site 926, and Site $872 \mathrm{~B} / \mathrm{Ca}$ records track the planktic $\delta^{11} \mathrm{~B}$-derived $\mathrm{pH}$ (i.e., $\mathrm{MCO}$ : low $\mathrm{pH}$, low $\mathrm{B} / \mathrm{Ca}$ ) in the same cores supporting the idea that $\mathrm{B} / \mathrm{Ca}$ is responding to global changes in surface ocean carbonate chemistry across the middle Miocene 29,30,35 $^{2}$ (Fig. 1 and Supplementary Fig. 2). Furthermore, the similar timing of change in the $\delta^{13} \mathrm{C}_{\mathrm{p}}$ and $\mathrm{B} / \mathrm{Ca}$ records across the middle Miocene suggests that the MCIE was associated with a change in the surface ocean carbon cycle and carbonate chemistry (Fig. 1).
The moderately resolved Indian Ocean T. trilobus $\mathrm{B} / \mathrm{Ca}$ record shows a $\sim 10 \mu \mathrm{mol} / \mathrm{mol}$ increase in $\mathrm{B} / \mathrm{Ca}$ associated with CM6 (Fig. 2 and Supplementary Fig. 3). As the resolution of the Pacific and Atlantic $\mathrm{B} / \mathrm{Ca}$ is too low to resolve short-term variations in surface ocean carbon storage, we look to the $T$. trilobus $\mathrm{B} / \mathrm{Ca}$ record across CM6 from the Blue Clay Formation of Malta at Ras il-Pellegrin 23,36 for comparison. This record shows an $\sim 17 \mu \mathrm{mol} /$ mol increase in $\mathrm{B} / \mathrm{Ca}$ with a corresponding increase in planktic $\delta^{11} \mathrm{~B}$-derived $\mathrm{pH}$. Together, the Indian Ocean and Malta records indicate surface ocean carbon reservoir changes associated with the short-term positive $\delta^{13} C_{p}$ variations (i.e., $C M$ events) in the global ocean (Supplementary Fig. 3).

Reconstructing Ocean Carbon Storage across the middle Miocene. Using surface ocean $\mathrm{pH}$ estimates derived from boron isotope reconstructions ${ }^{35}$ and ad hoc $\mathrm{B} / \mathrm{Ca}-\mathrm{B}(\mathrm{OH})_{4}-/ \mathrm{DIC}$ and $\mathrm{B} /$ $\mathrm{Ca}-\mathrm{B}(\mathrm{OH})_{4}{ }^{-} / \mathrm{HCO}_{3}{ }^{-}$calibrations (see Methods), we estimate changes in DIC and $\mathrm{B}(\mathrm{OH})_{4}{ }^{-} / \mathrm{HCO}_{3}{ }^{-}$across the middle Miocene (Figs. 3 and 4).

First, this approach allows us to identify the likely drivers of ocean carbonate system change during the middle Miocene through examining the relationship between Miocene surface ocean $\mathrm{B}(\mathrm{OH})_{4}{ }^{-} / \mathrm{HCO}_{3}{ }^{-}$and $\mathrm{pH}$ (Fig. 3). Changes in the ocean's biological and carbonate pumps lead to alterations of the vertical gradients of DIC and alkalinity (ALK), but not their overall inventory. Whereas long-term shifts in carbon fluxes can alter ocean inventories of DIC and ALK with the stabilizing response of carbonate compensation processes (i.e., $\mathrm{CaCO}_{3}$ dissolution and formation). Specifically, if the change in the carbonate system reconstructed was due to modification of the DIC or ALK gradient within the Miocene ocean (i.e., constant DIC or ALK), then the Miocene surface water $\mathrm{pH}$ vs. $\mathrm{B}(\mathrm{OH})_{4}{ }^{-} / \mathrm{HCO}_{3}{ }^{-}$would display a relationship with a relatively shallow slope (red and blue lines in Fig. 3). Similarly, if a change in these variables was due to whole-scale change in ALK:DIC with a 2:1 ratio due to carbonate compensation in response to changing the water column gradients, a shallow slope would result (green line in Fig. 3). DIC removal or addition due to the long-term geological processes (e.g., $\mathrm{CO}_{2}$ invasion, chemical weathering, and/or $\mathrm{C}_{\text {org }}$ burial/oxidation) where carbonate compensation operates to maintain a stable $\mathrm{CaCO}_{3}$ saturation state can be approximated by the purple line on Fig. 3 where ALK and DIC change with a 1:1 ratio. This results from the addition/removal of $1 \mathrm{~mol}$ of $\mathrm{CO}_{2}$ and the full carbonate compensation response that adds/removes ALK and DIC with a 2:1 ratio to maintain a steady state of $\mathrm{CaCO}_{3}$ burial $^{37}$. The Miocene $\mathrm{B}(\mathrm{OH})_{4}^{-} / \mathrm{DIC}$ and $\mathrm{pH}$ data show a relationship which closely follows the 1:1 (ALK:DIC) line, suggesting the changes in carbonate system we reconstruct (i.e. $\mathrm{pH}$ and $\left.\mathrm{B}(\mathrm{OH})_{4}{ }^{-} / \mathrm{HCO}_{3}{ }^{-}\right)$were mainly due to the addition/ removal of DIC through slow geological processes, coupled with the expected $\mathrm{CaCO}_{3}$ system response (Fig. 3).

This approach allows a semi-quantification of ocean DIC through the Miocene. However, given the inherent uncertainties involved, particularly in the $[\mathrm{B}]_{\mathrm{sw}}$ and the sensitivity of the $\mathrm{B} / \mathrm{Ca}$ $\left[\mathrm{B}(\mathrm{OH})_{4}{ }^{-} / \mathrm{DIC}\right]_{\mathrm{sw}}$, only relative changes in Miocene DIC are considered here (Fig. 4). Using this semi-quantitative approach, we are able to show that the low $\mathrm{B} / \mathrm{Ca}$ and $\mathrm{B}(\mathrm{OH})_{4}{ }^{-} / \mathrm{HCO}_{3}{ }^{-}$ values of the MCO suggest higher DIC levels in this warm interval, and that DIC had declined by $\sim 200$ to $400 \mu \mathrm{mol} / \mathrm{kg}$ by the end of the MMCT glaciation (see Methods and Fig. 4). Superimposed on this overall change in DIC on millions of years timescales are higher resolution changes in DIC that were likely orbitally paced. For example, paired $\delta^{11} \mathrm{~B}$ and $\mathrm{B} / \mathrm{Ca}$ records from Malta provide strong evidence for a DIC decline across the CM6 event (Supplementary Fig. 3). Although the absolute values 


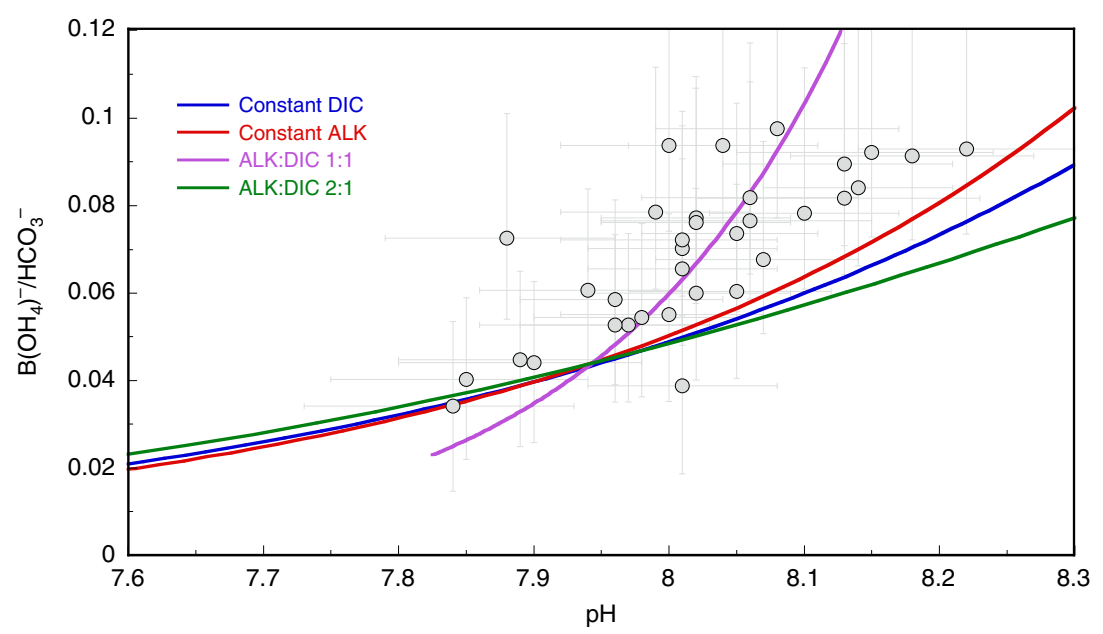

Fig. 3 Sensitivity of pH vs. $\left[\mathbf{B}(\mathbf{O H})_{\mathbf{4}}{ }^{-} / \mathbf{H C O}_{3}{ }^{-}\right]_{\mathbf{s w}}$ relationship to DIC and ALK. pH estimates derived from boron isotope reconstructions ${ }^{35}$ and ad hoc $\mathrm{B} /$ $\mathrm{Ca}-\mathrm{B}(\mathrm{OH})_{4}{ }^{-} / \mathrm{DIC}$ and $\mathrm{B} / \mathrm{Ca}-\left[\mathrm{B}(\mathrm{OH})_{4}{ }^{-} / \mathrm{HCO}_{3}{ }^{-}\right]_{\mathrm{sw}}$ calibrations (see Methods) are plotted for a range of scenarios with changes in the dissolved inorganic carbon (DIC) and alkalinity (ALK) inventory. Blue and red line indicate scenarios with constant DIC and ALK, respectively. Purple and green lines indicate changes with a ALK:DIC ratio of 1:1 and 2:1. We plot one $\delta^{11} B_{s w}{ }^{35,66}$ (G17) scenario to highlight the overall relationships present and provide full carbonate system estimates in the Methods. Monte Carlo uncertainty estimates $(95 \% \mathrm{Cl})$ are plotted for $\mathrm{pH}^{35}$ and $\left[\mathrm{B}(\mathrm{OH})_{4}^{-} / \mathrm{HCO}_{3}{ }^{-}\right]_{\mathrm{sw}}$ estimates.

remain poorly constrained we estimate this decline to be on the order of $\sim 300 \mu \mathrm{mol} / \mathrm{kg}$.

\section{Discussion}

Our planktic foraminiferal $\delta^{13} \mathrm{C}_{\mathrm{p}}$ records show the slow rise and peak during the $\mathrm{MCO}$, directly followed by a recovery during the MMCT, typical of the globally recognized MCIE. Given the original Monterey Hypothesis, one would expect the broad increase in $\delta^{13} \mathrm{C}$ associated with the onset of the MCIE to be associated with a decrease in seawater DIC. This is in contrast to our boronbased DIC reconstructions, which show a broad low in $\mathrm{B} / \mathrm{Ca}$ values, low $\mathrm{pH}$, and hence high DIC throughout the duration of the MCO (Figs. 3 and 4, and see Methods), whereas $\mathrm{Mg} / \mathrm{Ca}-\mathrm{SST}$ estimates indicate a $\sim 1.8^{\circ} \mathrm{C}$ warming (Fig. 1). These findings are therefore not consistent with an interpretation of increasing organic carbon burial in a cooling climate at the onset of the MCIE. Instead, it is consistent with a volcanic driver initiating the warmth of the MCO, which pushed the climate system into a less glaciated state with higher sea level. The majority of volcanic emissions from the CRB erupted between 16.7 and $15.9 \mathrm{Ma}$, which is approximately coincident with the onset of the $\mathrm{MCO}^{31}$ (Fig. 4). Several studies propose that CRB volcanism supplied the necessary carbon emissions to trigger and sustain higher than modern atmospheric $\mathrm{CO}_{2}$ concentrations $(\sim 470-630 \mathrm{ppm})$, and warm MCO climate sufficient to inhibit reglaciation of Antarctica $24,25,29-39$ (Fig. 4).

A rise of atmospheric $\mathrm{CO}_{2}$ and positive $\delta^{13} \mathrm{C}$ excursion (MCIE), despite the release of presumably isotopically depleted volcanic carbon (mantle value of $-5 \%$ ) may at face value seem implausible. However, the higher $\mathrm{CO}_{2}$ levels could act to increase ocean $\delta^{13} \mathrm{C}$ by changing the fractionation factor associated with photosynthetic fixation of carbon, offsetting the depleted volcanic $\mathrm{CO}_{2}$ contribution ${ }^{25}$. Alternatively, a relatively slow emission rate or a carbon isotope composition heavier than the traditional $-5 \%$ mantle value, possibly through metamorphic degassing of country rock, could more easily reconcile a positive MCIE with increasing $\mathrm{CO}_{2}$ levels. Separation of the $\delta^{18} \mathrm{O}_{\mathrm{b}}$ signal into temperature and $\delta^{18} \mathrm{O}_{\text {sw }}$ shows a decrease in seawater $\delta^{18} \mathrm{O}\left(\delta^{18} \mathrm{O}_{\mathrm{sw}}\right)^{21}$ heading into the MCO suggesting a rise in sea level (Fig. 4). This is supported by numerous records of ice volume and sea-level variability based on sedimentological and oxygen isotope evidence from the early to mid-Miocene, which indicates that the Antarctic ice sheet was highly variable during this interval with equivalent to $30-80 \%$ loss of modern Antarctic ice sheet $15,21,30,40-42$. It is therefore conceivable that this glacio-eustatic expansion of shelf area would lead to an enhanced capacity for continental organic carbon burial. As modern continental shelves produce three times the mean primary productivity of the ocean ${ }^{43}$ this can lead to organic-rich lowoxygen sediment conditions ideal for increased preservation of organic carbon during the MCO. Furthermore, shelf facies are typically associated with relatively high sedimentation rates, which also favors organic matter preservation and burial ${ }^{44}$. Despite this proposed propensity for enhanced organic carbon burial, elevated surface ocean DIC levels over millions of years could be sustained by the supply of carbon emissions via Columbia River Basalt eruptions. This mechanism would not be expected to cause an increase in productivity or organic carbon burial in open ocean sites, consistent with evidence from deep-water palaeoproductivity proxies ${ }^{45}$. The MCO sea level rise likely also stimulated enhanced shallow water carbonate deposition in suitable locations, representing an additional source of $\mathrm{CO}_{2}$ to the atmosphere ${ }^{46}$. The net effect on the carbon cycle is difficult to quantify as it would depend on the balance between the volcanic and chemical weathering fluxes, and the proportion of organic carbon to carbonate burial fluxes. Nevertheless, our records provide the first evidence to suggest that the MCIE was associated with high oceanic DIC that sustained enhanced organic carbon burial over millions of years (Fig. 4f). Overall, this implies a role for $\mathrm{CO}_{2}$ induced glacio-eustatic sea level rise in modulating the organic carbon subcycle and producing the largest carbon isotope excursion of the Neogene. The associated burial of marine organic carbon therefore represents a negative feedback, mitigating further atmospheric $\mathrm{CO}_{2}$ rise. We note that prior studies suggest that marine organic carbon accumulation rates within the Monterey Formation (eastern Pacific) are too low to account for the entire magnitude of the MCIE and additional light carbon enriched depocenters were proposed to reconcile the full magnitude of the carbon isotope excursion ${ }^{45-47}$. Here we look at this question with an ocean-based lens and note that additional studies are needed to explore the relative contribution of shelf vs. continental organic carbon sequestration (e.g., enhanced peat formation) in driving the MCIE.

Overall, our results suggest that during the MCO there is an increase in organic carbon burial as seen for the Early Eocene 


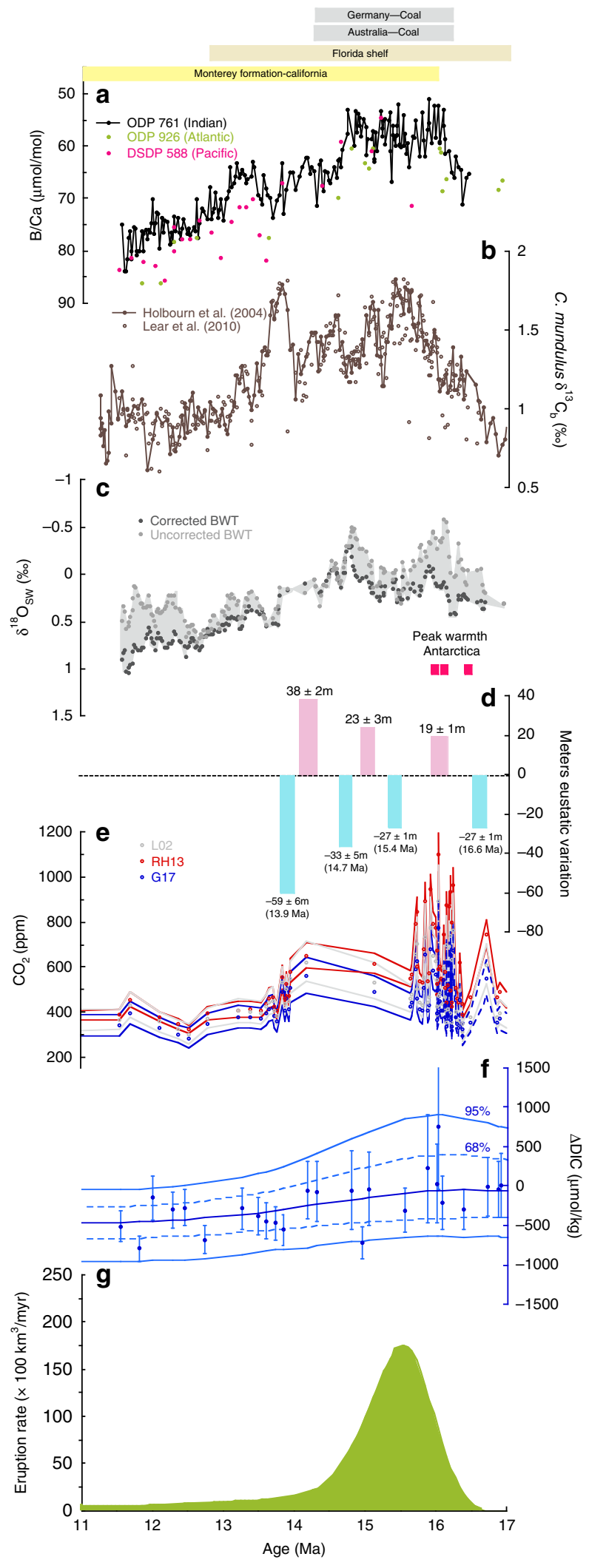

Climatic Optimum ${ }^{48}$ and Cretaceous OAEs ${ }^{33,34,49}$. This played a role in mitigating the volcanically driven rise in $\mathrm{CO}_{2}$, acting as a negative feedback. However, in contrast to the MCIE, the hallmark of OAE events are widespread anoxic and euxinic conditions. The greenhouse state during the Cretaceous had virtually
Fig. 4 Paleoclimate records across the middle Miocene. a Planktic foraminifera $T$. trilobus $B / C$ a ratios from Indian (ODP 761), Pacific (DSDP 588), and Atlantic Oceans (ODP 926) alongside (b) benthic foraminiferal $\delta^{13} \mathrm{C}^{14,21}$ records from ODP site 761. c Estimates of changes in global ice volume as derived from $\delta^{18} \mathrm{O}_{\mathrm{sw}}$ at ODP site 761 . Gray circles are uncorrected BWT estimates, whereas dark gray circles are corrected ${ }^{21}$. d Eustatic sea-level change from the Marion Plateau 40 . Intervals of peak warmth in Antarctica as identified from ANDRILL ${ }^{15}$ are highlighted with pink bars (PW3-5). e Boron isotope derived atmospheric $\mathrm{CO}_{2}$ record ${ }^{35}$ using three $\delta^{11} \mathrm{~B}_{\mathrm{sw}}$ scenarios $66,89,92$ (LO2; RH13; G17). f midMiocene DIC estimates with Monte Carlo uncertainty envelope using ad hoc $\mathrm{B} / \mathrm{Ca}-\mathrm{B}(\mathrm{OH})_{4}{ }^{-} / \mathrm{DIC}$ calibration. We plot one $\delta^{11} \mathrm{~B}_{\mathrm{sw}}$ scenario ${ }^{35,66}$ (G17) to highlight overall changes in DIC ( $\triangle \mathrm{DIC}$ ) changes and provide full range of DIC estimates in the Methods. Miocene DIC values were subtracted from average MCO DIC levels to calculate $\triangle$ DIC. $\mathbf{g}$ Estimated eruption rate of the Columbia River Basalt 93 . Top bars specify marine (yellow) and land based (green) organic carbon deposition events evident across the Miocene $\mathrm{e}^{19,94,95}$.

no continental ice and widespread warmth ${ }^{50,51}$. Furthermore, more sluggish ocean circulation due to the lack of polar ice and lower ocean oxygen content due to overall warmer ocean temperatures may have led to an increased capacity to produce an OAE in the early Cenozoic/Late Cretaceous. We conclude therefore that the MCIE was likely a failed OAE due to the presence of an Antarctic ice sheet and relatively well-ventilated ocean in an icehouse time interval.

Superimposed on the long-term broad MCIE and its recovery are short-lived $(400 \mathrm{kyr})$ carbon maxima events (CM1-6) associated with positive excursions in $\delta^{18} \mathrm{O}_{\mathrm{b}}$, glaciation/cooling and the long-term component of eccentricity ( $400 \mathrm{kyr})$, with CM6 having the largest amplitude ${ }^{16-18,20,52} \cdot \delta^{18} \mathrm{O}_{\mathrm{b}}$ leads benthic $\delta^{13} \mathrm{C}_{\mathrm{b}}$ in the eccentricity band in Miocene isotopic records indicating a lag of carbon cycle over climate variability ${ }^{19}$. Our planktic B/Ca record at ODP Site 761 exhibits similar short-term variability as $\delta^{18} \mathrm{O}_{\mathrm{b}}$ and $\delta^{13} \mathrm{C}_{\mathrm{b}}$ that is superimposed on the broad decrease in $\mathrm{B} / \mathrm{Ca}$, although the resolution of the record limits our ability to examine its possible orbital signature (Figs. 1, 2, and 4). An increase in $\mathrm{B} / \mathrm{Ca}$ associated with CM-6 evident from ODP Site 761 and Malta indicates a DIC decline (Supplementary Fig. 3). This suggests that although the broad positive MCIE is associated with relatively high DIC, the individual carbon maxima events are associated with higher $\mathrm{B} / \mathrm{Ca}$ (lower DIC), implying that different processes are responsible for the two features of the carbon isotope record.

Previous work has shown that CM-6 is associated with an invigoration in ocean circulation and increase in marine export productivity ${ }^{45,53,54}$ and $p \mathrm{CO}_{2}$ draw-down ${ }^{23}$, following a major period of Antarctic ice sheet expansion ${ }^{55}$. This is a similar situation to the glaciation and positive CIE which occurs at the Oligocene-Miocene boundary $(\sim 23 \mathrm{Ma})^{56}$. As with the MCO, these $\delta^{13} \mathrm{C}$ carbon isotope excursions are associated with enhanced carbon burial and potentially enhanced marine productivity.

Modeling studies have linked the origin of the long-period eccentricity pattern in the $\delta^{13} \mathrm{C}$ record to insolation driven changes in a marine biosphere productivity ${ }^{57}$ and increased weathering and nutrient input and marine productivity ${ }^{58}$. Datamodel comparisons show that the magnitude of $\delta^{13} \mathrm{C}$ change and the timing and frequency of $\mathrm{CM}$ events depends on a balance between orbitally driven changes in ice volume and hence sealevel and shelf deposition/weathering and marine productivity ${ }^{53}$. Overall, this suggests that $\mathrm{CM}$ events during the MCIE were linked to high nutrient delivery sustained by high $\mathrm{CO}_{2}$-driven 
weathering alongside insolation-driven marine productivity events. However, further work is needed to fully consider the global nutrient budget and role of insolation in setting the stage for Miocene CM events.

Our records therefore indicate that increased marine organic carbon burial exhibited contrasting time-scale dependent behavior during the middle Miocene: on short-term orbital timescales it acted as positive climate feedback during the orbitally paced $\mathrm{CM}$ cooling events, and on million year timescales it acted as a negative climate feedback, mitigating volcanic $\mathrm{CO}_{2}$ emissions during the MCO.

Overall, our records suggest planktic $\mathrm{B} / \mathrm{Ca}$ is a powerful proxy to explore the oceanic carbon cycle during large carbon cycle perturbation events. Our new DIC record represents the dynamic interaction between volcanic driven $\mathrm{CO}_{2}$ input, organic carbon burial, and weathering. The broad $\delta^{13} \mathrm{C}$ increase of the MCIE was associated with high surface ocean DIC concentration and the sustained warmth of the MCO. We propose that elevated carbon emissions associated with Columbia River Basalt Flood volcanism induced global warming and sea level rise, which enhanced organic carbon burial via the drowning of continental shelves. We suggest that the broad MCIE itself is therefore a consequence of this key negative feedback process. The icehouse climate state of the middle Miocene, with its continuous ocean ventilation likely prevented the regime of enhanced organic carbon preservation from developing into a full-blown $\mathrm{OAE}$ as seen in the greenhouse world of the Cretaceous. During the CM events of the Miocene, climatic cooling episodes triggered corresponding periods of increased marine productivity, which likely reduced surface ocean DIC and atmospheric $\mathrm{CO}_{2}$ and acted as a positive carbon cycle feedback process consistent with the original Monterey Hypothesis. The nature and expression of carbon cycle feedbacks in response to $\mathrm{C}$-addition are therefore state-dependent, and such feedbacks may be critical when exploring future carbon emission scenarios in Earth System models.

\section{Methods}

Age model and study sites. Samples from DSDP Site 588 and ODP sites 761 Hole $\mathrm{B}, 926$ Holes A/B, and 872 Hole $\mathrm{C}$ were used to reconstruct SST and $\left[\mathrm{B}(\mathrm{OH})_{4}^{-} / \mathrm{DIC}\right]_{\mathrm{sw}}$ across the early to middle Miocene (22.0-11.5 Ma; Supplementary Fig. 1). Planktic foraminifera $\mathrm{Mg} / \mathrm{Ca}, \mathrm{B} / \mathrm{Ca}$, and $\delta^{13} \mathrm{C}_{\mathrm{p}}$ records from ODP site $761 \mathrm{~B}$ were sampled at an average temporal resolution of $23 \mathrm{kyr}$. In contrast, our other sites were sampled at lower resolution for B/Ca: ODP $926(\sim 200 \mathrm{kyr})$ and DSDP $588(\sim 100 \mathrm{kyr})$ and ODP $872(\sim 1 \mathrm{Myr})$. ODP $761\left(16^{\circ} 44.23^{\prime} \mathrm{S}, 115^{\circ} 32.10^{\prime} \mathrm{E}\right.$, water depth of $2179 \mathrm{~m}$ ) is situated in the Indian Ocean on the Wombat Plateau. Site ODP $926\left(3^{\circ} 43.148^{\prime} \mathrm{N}, 42^{\circ} 54.507^{\prime} \mathrm{E}\right.$, water depth $\left.3598 \mathrm{~m}\right)$ in the eastern equatorial Atlantic Ocean on Ceara Rise. Site DSDP 588 A $\left(26^{\circ} 06.7^{\prime} \mathrm{S}, 1^{\circ} 1^{\circ} 13.6^{\prime} \mathrm{E}\right.$ water depth $1548 \mathrm{~m}$ ) in the Southwest Pacific Ocean on Lord Howe Rise. ODP Site $872\left(10^{\circ} \mathrm{N}, 162^{\circ} \mathrm{E}, 1287 \mathrm{~m}\right.$ water depth) is in the tropical north Pacific gyre on the sedimentary caps of flat-topped seamounts.

The age model for Site 761B is based on a fourth-order polynomial fit through the biostratigraphic and isotopic datums ${ }^{14,35}$. For ODP site 926 , we use a polynomial fit through nannofossil and planktic foraminifer biostratigraphic datums adapted to the CK95 timescale ${ }^{35}$. The published age model for DSDP $588^{59}$ is based on compiled biostratigraphy, magnetostratigraphy, isotope stratigraphy calibrated to CK95. Ages for ODP Site 872 were calculated by linear interpolation between reliable biostratigraphic datums ${ }^{60}$ from the early to mid-Miocene adapted to the CK95 timescale ${ }^{35}$. Core sites ${ }^{29,30,35,61}$ used in this study were selected because currently they are located in regions where modern surface waters are close to equilibrium with respect to atmospheric $\mathrm{CO}_{2}$ (Supplementary Fig. 1). We use $\delta^{11} \mathrm{~B}-\mathrm{pH}$ estimates ${ }^{35}$ from ODP sites 761,872 , and 926 in addition to $\mathrm{B} / \mathrm{Ca}$ presented in this study to estimate surface ocean $\left[\mathrm{B}(\mathrm{OH})_{4}^{-} / \mathrm{DIC}\right]_{\mathrm{sw}}$ and $\left[\mathrm{B}(\mathrm{OH})_{4}^{-} / \mathrm{HCO}_{3}-\right]_{\mathrm{SW}}$

Planktic foraminiferal taxonomy and ecology. We generated trace element and isotope records using $T$. trilobus, a multi-chambered, photosymbiont bearing species, which is predominantly a mixed layer dweller calcifying at $0-50 \mathrm{~m}$ and is abundant in subtropical and tropical oceans. T. trilobus is a morphospecies of Trilobatus sacculifer ${ }^{62,63}$ present throughout the Neogene and Quaternary periods. T. trilobus has been used extensively in previous Miocene climate and boron isotope studies $29,23,30,35$ due to its narrow habitat range, well-defined $\delta^{11} \mathrm{~B}-\mathrm{pH}$ calibration, calcification close to equilibrium conditions (i.e., minimal vital effects), and abundance $29,35,63,64$. Further, previous studies demonstrated that temperatures derived from $T$. sacculifer are most suitable for estimating annual mean SST ${ }^{65}$ in tropical waters (between $20^{\circ} \mathrm{N} / \mathrm{S}$ ) within $\pm 1{ }^{\circ} \mathrm{C}$. Visual inspection of preservation (Supplementary Fig. 4) of T. trilobus from ODP site 761B show moderately good preservation with no visible signs of infilling or dissolution. Visual inspection of foraminiferal specimens from ODP site 926 shows evidence of a recrystallized nature, however the $\mathrm{Mg} / \mathrm{Ca}$ and boron isotope signature has remained intact ${ }^{29,35,66}$. Visual inspection of foraminiferal specimens from ODP site 872 show a glassy nature indicative of well-preserved specimens and exceptionally good carbonate preservation supported by previous work using scanning electron microscopic (SEM) images ${ }^{60,67}$. Visual inspection of foraminiferal specimens from DSDP 588 have been shown to be pristine in nature with no evidence of dissolution and have been previously used in oxygen isotope reconstructions ${ }^{52}$.

Trace metal and isotopic analysis. Between 30-40 tests of the planktic foraminifera $T$. trilobus were picked from the $300-355 \mu \mathrm{m}$ size fraction from ODP site 761,926 , and DSDP 588. ODP 872 samples were prepared for boron isotope analysis and an aliquot of the foraminiferal sample was used to collect trace element data (see ref. ${ }^{35}$ ). Picked specimens were weighed, gently crushed between glass plates and homogenized for chemical cleaning and geochemical analysis. In samples where T. trilobus abundance was low ( 30 samples), fewer specimens (10-20 individuals) were analyzed. After sample homogenization, an aliquot of the foraminiferal sample was used to collect trace element and $\delta^{13} \mathrm{C}_{\mathrm{p}}$ data. It is noteworthy that only $\delta^{13} \mathrm{C}_{\mathrm{p}}$ from ODP site 761 are presented here.

Test fragments for $\mathrm{Mg} / \mathrm{Ca}$ and $\mathrm{B} / \mathrm{Ca}$ analyses were cleaned using a protocol to remove surficial clays, adhered organic matter, and potential secondary carbonate overgrowths ${ }^{68}$. Clay removal consists of repeated rinses with low boron Milli-Q water and methanol. The oxidative cleaning step consists of a sodium hydroxide and hydrogen peroxide solution to remove any present organic matter. The reductive cleaning step was not included in the cleaning process as this step is unnecessary for $\mathrm{B} / \mathrm{Ca}$ as the cleaning does not alter the $\mathrm{B} / \mathrm{Ca}$ ratio of foraminifera or calcite bound boron ${ }^{69}$. Lastly, a weak acid leach using $0.001 \mathrm{M}$ hydrochloric acid was conducted to remove any ions re-absorbed during the cleaning process on the test surface. Following the clay removal and oxidative steps, samples were examined under a binocular microscope and visible non-carbonate particles were removed using a fine paintbrush. Cleaned, treated samples were dissolved in trace metal pure $0.065 \mathrm{M} \mathrm{HNO}_{3}$ and diluted with trace metal pure $0.5 \mathrm{M} \mathrm{HNO}_{3}$ to a final volume of $350 \mu \mathrm{l}$, to achieve a target calcium concentration of $4 \mathrm{mM}$. Trace element analysis (B, Mg, Al, Ca, Mn, Fe) for ODP 761, ODP 926, and DSDP 588 was carried out at Cardiff University on a Thermo Scientific Element XR Sector Field Inductively Coupled Plasma Mass Spectrometer (SF-ICP-MS), whereas samples from ODP site 872 were analyzed at the University of Southampton, using a Thermo Scientific Element 2 XR SF-ICP-MS. In both instances, calcium concentrations of bracketing standards were matched to foraminifera samples to reduce matrix effects ${ }^{70,71}$

To monitor the possibility of clay contamination $\mathrm{Mg} / \mathrm{Ca}$ and $\mathrm{B} / \mathrm{Ca}$ data were rejected if $\mathrm{Al} / \mathrm{Ca}$ exceeded $80 \mu \mathrm{mol} / \mathrm{mol}$ for all sites. Additional cleaning effectiveness was supported by observing no significant correlation between $\mathrm{Mg} / \mathrm{Ca}$, and $\mathrm{Fe} / \mathrm{Ca}$ and $\mathrm{Mn} / \mathrm{Ca}$ (Supplementary Figs. 5-6). There is no correlation between $\mathrm{B} / \mathrm{Ca}$ and $\mathrm{Fe} / \mathrm{Ca}$ at any of the investigated sites. There is however a positive correlation between $\mathrm{Mn} / \mathrm{Ca}$ and $\mathrm{B} / \mathrm{Ca}$ at ODP site $926\left(R^{2}=0.4\right)$ and $761\left(R^{2}=\right.$ $0.6)$, and a slight negative correlation $\left(R^{2}=0.3\right)$ between $\mathrm{Mn} / \mathrm{Ca}$ and $\mathrm{B} / \mathrm{Ca}$ at ODP site 872 (Supplementary Fig. 6). However, at site 761, correlations across $500 \mathrm{kyr}$ windows from 16.5 to $11.5 \mathrm{Ma}$ show no significant correlation $\left(R^{2}<0.3 ; p>0.05\right)$ between these variables in 8 out of the 10 intervals (Supplementary Table 1). We therefore propose here that the $\mathrm{Mn} / \mathrm{Ca}$ record reflects another aspect of the system (e.g., oxygenation, productivity), which would be correlated on geological timescales with $\mathrm{B} / \mathrm{Ca}$ as in the Miocene ${ }^{72}$. Long-term precision at Cardiff University and University of Southampton was determined by analyzing an independent consistency standard during each run for 1 year. Reported values are $0.5 \%$ and $4 \%$ (r.s.d.) for $\mathrm{Mg} / \mathrm{Ca}$ and $\mathrm{B} / \mathrm{Ca}$, respectively, for analyses at Cardiff University and $2 \%$ and $4 \%$ (r.s.d.) for $\mathrm{Mg} / \mathrm{Ca}$ and $\mathrm{B} / \mathrm{Ca}$, respectively, for analyses at University of Southampton.

Stable carbon isotope ratios were measured at Cardiff University on a Finnigan MAT 252 micro-mass spectrometer Kiel III Carbonate Device when sample weights were $<100 \mu \mathrm{g}$ and measured on a Delta isotope ratio mass spectrometer when samples were greater than $100 \mathrm{ug}$. Long-term precision based on replicate measurements of a laboratory standard (NBS 19) are $0.08 \%$ or for $\delta^{13} \mathrm{C}$.

\section{$\mathbf{M g} / \mathrm{Ca}$-paleotemperature calculation and constraining $\mathbf{M g} / \mathbf{C a}$ seawater} changes. Planktic T. trilobus is the morphotype of the modern T. sacculifer, we consider it appropriate to calculate mean annual SSTs from T. trilobus $\mathrm{Mg} / \mathrm{Ca}$ data using the T. sacculifer calibration 65 .

$$
\frac{M g}{C a}=0.347( \pm 0.011) e^{0.090( \pm 0.003) T}
$$

Variations in Miocene foraminiferal $\mathrm{Mg} / \mathrm{Ca}$ are driven by changes in temperature; however, on longer timescales, both changes in temperature and in seawater $\mathrm{Mg} / \mathrm{Ca}$ must be considered. Recently, it has been shown that a power 
function $^{73}$ best describes this relationship.

$$
\frac{M g}{C a_{\text {foram }}}=\left[\frac{\frac{M g}{C a_{s w}}(t)}{\frac{M g}{C a_{s w}}(0)}\right]^{C} B e^{A T}
$$

where $\mathrm{Mg} / \mathrm{Ca}_{\text {sw }}(\mathrm{t})$ and $\mathrm{Mg} / \mathrm{Ca}_{\text {sw }}(0)$ are seawater $\mathrm{Mg} / \mathrm{Ca}$ ratios for the Miocene and present, and $\mathrm{A}, \mathrm{B}$, and $\mathrm{C}$ are constants $(\mathrm{A}=$ exponential, $\mathrm{B}=$ pre-exponential, $\mathrm{C}=$ power constant), respectively.

$\mathrm{Mg}$ and Ca have relatively long residence times ( 13 Myr and $\sim 1.1 \mathrm{Myr}$, respectively) in the ocean. The modern day seawater $\mathrm{Mg} / \mathrm{Ca}$ value is $5.2 \mathrm{mmol} / \mathrm{mol}$ and low-resolution fluid inclusions data ${ }^{74}$ show a rise across the Neogene to the modern values. Here we use the fluid inclusion value of $3.43 \mathrm{mmol} / \mathrm{mol}$ in the paleotemperature calculation. We use the T. sacculifer calibration ${ }^{65}(A=0.09, B=$ 0.347 ) for T. trilobus and apply a power constant ${ }^{75}$ of 0.41 for $T$. Sacculifer based on the available data for this species ${ }^{76}$. T. trilobus SST estimates can be calculated from the following equation:

$$
\frac{M g}{C a \text { foram }}=0.293 e^{0.090 T}
$$

Using a range of $\mathrm{Mg} / \mathrm{Ca}$ seawater estimates, calculated SST during the MCO period in Site 761 ranges from $1.4^{\circ} \mathrm{C}$ warmer to uncorrected $\mathrm{Mg} / \mathrm{Ca}$-SST estimates being cooler by $0.5^{\circ} \mathrm{C}$ than the modern (modern mean annual temperature is $\sim 27.7^{\circ} \mathrm{C}$ ).

In addition to changes in seawater $\mathrm{Mg} / \mathrm{Ca}, \mathrm{Mg}$ incorporation in foraminifera has shown a species-specific dependency to changes in carbonate chemistry. A recent review ${ }^{77}$ proposed a $\mathrm{pH}$ correction was necessary to correct $\mathrm{Mg} / \mathrm{Ca}$ records when estimating SST for some species. This study showed that $\mathrm{Mg} / \mathrm{Ca}$ ratios in $T$. sacculifer are insensitive to changes in $\mathrm{pH}$. As $\mathrm{Mg} / \mathrm{Ca}$ ratios are derived from $T$. trilobus shells, the morphotype of $T$. sacculifer, we apply no $\mathrm{pH}$ correction in this study.

Foraminiferal preservation. Several lines of evidence suggest that dissolution does not significantly affect the $\mathrm{Mg} / \mathrm{Ca}$ or $\mathrm{B} / \mathrm{Ca}$ values at Site 761 and suggest our data represent a climate signal. First, ODP Site 761 is situated well above the modern lysocline, above the critical $20 \mu \mathrm{mol} / \mathrm{kg} \Delta \mathrm{CO}_{3}{ }^{2-}$, in a relatively shallow burial depth during the middle Miocene $(<50 \mathrm{~m})\left(\mathrm{GLODAP}^{78}\right)$. Average shell weight of $T$. trilobus, from the $300-355 \mu \mathrm{m}$ size fraction, does not covary with the $\mathrm{Mg} / \mathrm{Ca}$ or B/ $\mathrm{Ca}$ record, supporting our argument that these values are not biased (Supplementary Fig. 7)

Despite the reasonable appearance of foraminifera, all tests appear frosty or opaque in contrast to exceptionally well-preserved translucent test shells from hemipelagic muds ${ }^{79}$. However, this preservation state is typical of most deep-sea carbonates and is caused by micro-recrystallization of calcite. Large-scale recrystallization is not evident in SEM images for ODP site 761 (Supplementary Fig. 4), suggesting that diagenesis did not drive prominent shifts in $\delta^{13} \mathrm{C}$ and trace elements. In addition, $\mathrm{Sr} / \mathrm{Ca}$ ratios from ODP site 761 show high values $(\sim 1.1-1.2$ $\mathrm{mmol} / \mathrm{mol}$; Supplementary Table 2), which are consistent across much of the record, suggesting that diagenesis did not have a major influence on $\mathrm{Mg} / \mathrm{Ca}$ or $\mathrm{B} /$ $\mathrm{Ca}$ variations. Nonetheless, $\mathrm{Mg} / \mathrm{Ca}$ values decrease by a negligible amount with initial diagenetic alteration ${ }^{79}$, thus temporal changes in $\mathrm{Mg} / \mathrm{Ca}$ are less likely to be affected. Further work ${ }^{80}$ has shown a decrease in planktic B/Ca in recrystallized relative to well-preserved foraminifera; however, additional work is needed to isolate the primary diagenetic signal. For the reasons outlined above, we believe that diagenesis had a minimal effect on our records and we therefore interpret the geochemical records in terms of paleoceanographic conditions.

\section{Estimation of surface ocean $\left[\mathrm{B}(\mathrm{OH})_{4}-/ \mathrm{HCO}_{3}{ }^{-}\right]_{\text {sw }}$ and $\left[\mathrm{B}(\mathrm{OH})_{4}-/ \mathrm{DIC}\right]_{\mathrm{sw}}$ from} $\mathbf{B} / \mathbf{C a}$. Similar to boron isotopes, the boron content (expressed as $\mathrm{B} / \mathrm{Ca}$ ) of planktic foraminifera has been suggested to be a proxy for ocean carbonate chemistry 69,81 . Boron exists in seawater primarily as two species borate $\left(\mathrm{B}(\mathrm{OH})_{4}{ }^{-}\right.$and boric acid $\left(\mathrm{B}(\mathrm{OH})_{3}\right)$, and the relative concentration of each boron species and their $\delta^{11} \mathrm{~B}$ composition varies with $\mathrm{pH}$ in seawater. Boron isotopic evidence and other arguments suggest that $\mathrm{B}(\mathrm{OH})_{4}{ }^{-}$is the species predominantly incorporated into the foraminiferal calcite lattice ${ }^{82}$. $\mathrm{B} / \mathrm{Ca}$ in planktic foraminifera is controlled by a combination of ocean carbonate chemistry parameters $\left(\mathrm{pH}, \mathrm{B}(\mathrm{OH})_{4}{ }^{-} \mathrm{HCO}_{3}^{-}\right.$and DIC) as demonstrated through empirical culture experiments and field studies $71,81,83$. Culturing efforts aimed to disentangle this co-varying carbonate system parameters show that $\mathrm{B} / \mathrm{Ca}$ is governed principally by the ratio of seawater $\mathrm{B}(\mathrm{OH})_{4}^{-}$to DIC or $\mathrm{HCO}_{3}^{-81,84}$. Application of the $\mathrm{B} / \mathrm{Ca}$ proxy to reconstruct shifts in the concentration of $\left[\mathrm{B}(\mathrm{OH})_{4}{ }^{-} / \mathrm{DIC}\right]$ in seawater across major climate transitions has shed light on past carbon cycle perturbations ${ }^{84,85}$ (e.g., PaleoceaneEocene Thermal Maximum), where large shifts in the ocean carbonate system occurred. Similarly, in our study we aim to examine the carbon cycle perturbations of the early to middle Miocene, a time interval whereby a large carbonate system shifts likely occurred, suggesting some of the complexities that others have discussed with regard to the glacial-interglacial cycles may not be significant.

Culture experiments with living T. sacculifer demonstrate a positive relationship between $\mathrm{B} / \mathrm{Ca}$ and oceanic carbonate system parameters, where $\mathrm{B} / \mathrm{Ca}$ increases at higher $\mathrm{pH}$ and lower DIC and $\mathrm{HCO}_{3}{ }^{-}$concentrations (Supplementary Fig. 8) ${ }^{81}$. These experiments also provide calibrations that relate $\mathrm{B} / \mathrm{Ca}$ to both $\left[\mathrm{B}(\mathrm{OH})_{4}{ }^{-}\right.$-
$\left.\mathrm{HCO}_{3}{ }^{-}\right]_{\mathrm{sw}}$ and $\left[\mathrm{B}(\mathrm{OH})_{4}{ }^{-} / \mathrm{DIC}\right]_{\mathrm{sw}}$; however, they argue for a better fit to the latter parameter. Recent culture work further explored the mechanistic understanding of $\mathrm{B}$ uptake, indicating that planktic $\mathrm{B} / \mathrm{Ca}$, Orbulina universa specifically, is driven by $\mathrm{HCO}_{3}{ }^{-}$in support of $\left[\mathrm{B}(\mathrm{OH})_{4}{ }^{-} / \mathrm{HCO}_{3}{ }^{-}\right]_{\mathrm{sw}}$ rather than $\left[\mathrm{B}(\mathrm{OH})_{4}{ }^{-} / \mathrm{DIC}\right]_{\mathrm{sw}}$ controlling $\mathrm{B} / \mathrm{Ca}^{83}$. Here we present $\left[\mathrm{B}(\mathrm{OH})_{4}{ }^{-} / \mathrm{HCO}_{3}{ }^{-}\right]_{\text {sw }}$ to evaluate the main drivers of carbonate system change through the MCIE. Further, we consider both $\mathrm{B} / \mathrm{Ca}$ carbonate chemistry sensitivities (e.g., $\left[\mathrm{B}(\mathrm{OH})_{4}{ }^{-} / \mathrm{HCO}_{3}{ }^{-}\right]_{\mathrm{sw}}$ and $\left[\mathrm{B}(\mathrm{OH})_{4}{ }^{-} /\right.$ DIC $]_{\text {sw }}$ ) to estimate surface ocean DIC.

When we compile all available $\mathrm{B} / \mathrm{Ca}-\left[\mathrm{B}(\mathrm{OH})_{4}{ }^{-} / \mathrm{DIC}\right]_{\mathrm{sw}}$ and $\left[\mathrm{B}(\mathrm{OH})_{4}{ }^{-} /\right.$ $\left.\mathrm{HCO}_{3}{ }^{-}\right]_{\mathrm{sw}}$ T. sacculifer calibration data, an offset is observed between culture ${ }^{81}$ and core-top ${ }^{86}$ datasets, where the core-top data sits lower and with a slightly steeper slope predicted by culture experiments, although this slope difference may largely be a function of the different ranges spanned by the datasets, as the available coretop data are limited by the range in surface ocean carbonate chemistry (e.g., [B $\left.\left.(\mathrm{OH})_{4}-/ \mathrm{DIC}\right]_{\mathrm{sw}}\right)$ that span the depth habitat of wild-type T. sacculifer compared with conditions manipulated in culture work ${ }^{81}$. We account for differences in test size $^{87}$ and normalize values to a common salinity $(S=35)^{81}$, but an offset and slope difference between the datasets remain (Supplementary Fig. 8). Here we suggest the offset could be related to the fact core-top foraminiferal specimens, during their life cycle, sink to water with lower $\mathrm{pH}$ and higher $\mathrm{DIC} / \mathrm{HCO}_{3}{ }^{-}$in contrast to the cultured specimens. This is supported by the lower core-top $\mathrm{B} / \mathrm{Ca}$ values relative to culture. Furthermore, the core-top study used T. sacculifer specimens with the final sac-life chamber, which have lower B/Ca relative to nonsac chambers ${ }^{81}$, in contrast to the cultured specimens.

To address the $\mathrm{B} / \mathrm{Ca}$ offset between datasets we retain the slope predicted in culture and normalize the culture to core-top values to generate new ad hoc $\mathrm{B} / \mathrm{Ca}$ to $\left[\mathrm{B}(\mathrm{OH})_{4}{ }^{-} / \mathrm{DIC}\right]_{\mathrm{sw}}$ and $\left[\mathrm{B}(\mathrm{OH})_{4}{ }^{-} / \mathrm{HCO}_{3}{ }^{-}\right]_{\mathrm{sw}}$ calibrations $\left(\mathrm{B} / \mathrm{Ca}=33+773^{*}[\mathrm{~B}\right.$ $\left.(\mathrm{OH})_{4}{ }^{-} / \mathrm{DIC}\right]_{\mathrm{sw}} ; \mathrm{B} / \mathrm{Ca}=39+561^{*}\left[\mathrm{~B}(\mathrm{OH})_{4}{ }^{-} / \mathrm{HCO}_{3}{ }^{-}\right]_{\mathrm{sw}}$; Supplementary Fig. 8). Application of these ad hoc calibrations to ODP $761 \mathrm{~B} / \mathrm{Ca}$ reconstructions requires additional consideration of past changes in seawater boron $\left(\left[\mathrm{B}_{\mathrm{sw}}\right]\right)$ on calibration sensitivity. We can assume a constant seawater composition over the studied interval as it is considerably shorter than the oceanic residence time of B (10-20 million years $)^{88}$. A positive relationship between seawater $B$ concentration $\left(\left[\mathrm{B}_{\mathrm{sw}}\right]\right)$ and $\mathrm{B}$ content in planktic foraminiferal calcite $(O$. universa) is observed in culture experiments $^{81,83,84}$ (Supplementary Fig. 9). Following $\mathrm{Mg} / \mathrm{Ca}$ convention and the observation that $\mathrm{Mg} / \mathrm{Ca}$ sensitivity changes as a function of seawater $\mathrm{Mg} / \mathrm{Ca}$ ratio, we adjust the calibration sensitivity to changes in $\mathrm{B} / \mathrm{Ca}_{\mathrm{sw}}$, to account for the influence of variable $\mathrm{Mg} / \mathrm{Ca}_{\mathrm{sw}}$ on $\mathrm{Mg} / \mathrm{Ca}$ thermometry ${ }^{70,75}$ by assuming a linear scaling:

$$
\begin{gathered}
\frac{B}{C a} \text { foram }=\frac{\frac{B}{C a} s w t=t}{\frac{B}{C a} s w t=0} x \frac{B(\mathrm{OH})_{4}^{-}}{\mathrm{HCO}_{3}^{-}} * m+b \\
\frac{B}{C a} \text { foram }=\frac{\frac{B}{C a} s w t=t}{\frac{B}{C a} s w t=0} x \frac{B(\mathrm{OH})_{4}^{-}}{\mathrm{DIC}} * m+b
\end{gathered}
$$

where $B / C a_{s w}(t=t)$ for the age of the sample and $B / C a_{s w}(t=0)$ is modern $\mathrm{B} / \mathrm{Ca}_{\mathrm{sw}}$ and $m$ and $b$ are the slope and $\mathrm{y}$-intercept for each calibration from. Miocene estimates of $\mathrm{B}_{\mathrm{sw}}$ and $\mathrm{Ca}_{\mathrm{sw}}$ are derived from boron isotope modeling and fluid inclusion estimates, respectively ${ }^{74,88}$.

Calculation of DIC and $\mathrm{HCO}_{3}{ }^{-}$from the $\mathrm{B} / \mathrm{Ca}-\left[\mathrm{B}(\mathrm{OH})_{4}{ }^{-} / \mathrm{DIC}\right]_{\mathrm{sw}}$ and $[\mathrm{B}$ $\left.(\mathrm{OH})_{4}{ }^{-} / \mathrm{HCO}_{3}{ }^{-}\right]_{\mathrm{sw}}$ calibrations requires an independent estimate of $\mathrm{B}(\mathrm{OH})_{4}{ }_{-}^{-}$ across the Miocene, and here we use $\delta^{11} \mathrm{~B}-\mathrm{pH}$ estimates from ODP 761, 872, and $926^{35}$ to calculate $\mathrm{B}(\mathrm{OH})_{4}{ }^{-} . \mathrm{B}(\mathrm{OH})_{4}{ }^{-}$is related to $\mathrm{pH}$ as described here:

$$
\begin{gathered}
\mathrm{pH}=-\log \left[H^{+}\right] \\
B(\mathrm{OH})_{4}^{-}=B_{\text {TOT }} /\left(1+\frac{\left[H^{+}\right]}{K_{\mathrm{B}}^{*}}\right)
\end{gathered}
$$

where $K_{\mathrm{B}}^{*}$ is the stoichiometric equilibrium constant for boric acid ${ }^{89}$ at time equivalent $T, S$, and $P$, and $\mathrm{Mg} / \mathrm{Ca}_{\mathrm{sw}}(t=X \mathrm{Ma})$. $\mathrm{pH}$ estimates used were derived from the three $\delta^{11} \mathrm{~B}_{\mathrm{sw}}$ scenarios ${ }^{35}$ (G17, RH13, L02). The $\mathrm{pH}$ derived from each scenario have a similar structure but differ in absolute $\mathrm{pH}$ values. This should minimally impact the DIC trend across the Miocene, however, we use $\mathrm{pH}$ estimates from all scenarios to estimate the likely DIC (Supplementary Fig. 10). Surface ocean $\mathrm{pH}$ estimates from ODP 872 are higher by $0.1 \mathrm{pH}$ units compared with site 926 and 761 in the early Miocene (16.5-17.0 Ma) (Supplementary Fig. 2). To account for this offset, we adjust ODP site 872 by $0.1 \mathrm{pH}$ units and use these adjusted $\mathrm{pH}$ values in the DIC estimates. SST estimates are derived from $\mathrm{Mg} / \mathrm{Ca}$ in complementary samples ${ }^{35}$ and modern salinity is assumed for the entire duration of the Miocene record. We normalize planktic $\mathrm{B} / \mathrm{Ca}$ values to a common salinity, assuming modern salinity values for each site $(S=35)^{81}$. $\mathrm{B}_{\mathrm{sw}}$ varied in time according to marine boron isotope budget ${ }^{88}$ in the same manner as above for $\mathrm{B} / \mathrm{Ca}_{\mathrm{sw}}$ estimates. Using the $\mathrm{B} / \mathrm{Ca}-\left[\mathrm{B}(\mathrm{OH})_{4}{ }^{-} / \mathrm{HCO}_{3}{ }^{-}\right]_{\mathrm{sw}}$ calibration, we estimate DIC from $\mathrm{HCO}_{3}{ }^{-}$ using the following equation:

$$
\mathrm{DIC}=\frac{\left[\mathrm{H}^{+}\right]\left[\mathrm{HCO}_{3}^{-}\right]}{K_{1}}+\left[\mathrm{HCO}_{3}^{-}\right]+\frac{K_{2}\left[\mathrm{HCO}_{3}^{-}\right]}{\left[\mathrm{H}^{+}\right]}
$$

where $K_{1}$ and $K_{2}$ are the carbonic acid dissociation constants ${ }^{89}$

The principal uncertainties in calculating $[\mathrm{DIC}]_{\mathrm{sw}}$ and $\left[\mathrm{HCO}_{3}{ }^{-}\right]$in this way were judged to be uncertainties in the $\mathrm{B} / \mathrm{Ca}$ calibration and in the $\mathrm{pH}$ used to 
calculate $\left[\mathrm{B}(\mathrm{OH})_{4}^{-}\right]$. Here we used Monte Carlo method to propagate these uncertainties into our final estimates of DIC and $\mathrm{HCO}_{3}{ }^{-}$. In order to highlight the long-term trends in DIC and $\mathrm{HCO}_{3}{ }^{-}$, we then fit smoothing splines through the data with the degree of smoothing determined by generalized cross validation. Again, the uncertainty in these smoothed trends was determined using a Monte Carlo approach and a consideration of the error bars of each individual estimate.

DIC estimates derived using the range of $\mathrm{pH}$ scenarios (G17 v RH13 v L02) show a similar trend across the middle Miocene (Supplementary Fig. 11). Miocene estimates of surface ocean DIC derived from ODP site 761 using both B/Ca-[B $\left.(\mathrm{OH})_{4}{ }^{-} / \mathrm{DIC}\right]_{\mathrm{sw}}$ and $\left[\mathrm{B}(\mathrm{OH})_{4}{ }^{-} / \mathrm{HCO}_{3}{ }^{-}\right]_{\mathrm{sw}}$ calibrations, and $\mathrm{pH}$ estimates from all scenarios show higher DIC during the MCO (14.0-17.0 Ma; Supplementary Fig. 11 and Supplementary Tables 3 and 4; 68\% CI; $n=15)$. Early Miocene $(17.0-22.0 \mathrm{Ma})$ estimates are lower than the MCO (Supplementary Table 3; 68\% CI; $n=7$ ) increasing towards the onset of the MCO. MCO DIC estimates decline following the MMCT. MMCT DIC levels (13.5-11.0 Ma) are lower than the MCO (Supplementary Table 3; 68\% Confidence Interval; $n=12$ ). Further, the overall decline in DIC from the MCO to post-MMCT of $\sim 220$ to $370 \mu \mathrm{mol} / \mathrm{kg}$ (B/Ca-[B $\left.\left.(\mathrm{OH})_{4}{ }^{-} / \mathrm{DIC}\right]_{\mathrm{sw}}\right)$ and 280 to $430 \mu \mathrm{mol} / \mathrm{kg}\left(\mathrm{B} / \mathrm{Ca}-\left[\mathrm{B}(\mathrm{OH})_{4}{ }^{-} / \mathrm{HCO}_{3}{ }^{-}\right]_{\mathrm{sw})}\right.$ (Supplementary Table 5) is similar to change derived from a modeling study ${ }^{25}$, although absolute values are offset. Absolute Miocene DIC estimates here fall within the general estimates based on a range of approaches from modeling to geochemical reconstructions (Supplementary Fig. 12) 35,90,91.

Regardless of the approach and location, our findings suggest the MCO DIC levels were higher than the early Miocene and late middle Miocene and DIC levels decreased across the MMCT by as much as $200-400 \mu \mathrm{mol} / \mathrm{kg}$. Given the inherent uncertainties in these calculations, particularly in the $[\mathrm{B}]_{\mathrm{sw}}$ and the sensitivity of the $\mathrm{B} / \mathrm{Ca}-\left[\mathrm{B}(\mathrm{OH})_{4}{ }^{-} / \mathrm{DIC}\right]_{\mathrm{sw}}$ and $\left[\mathrm{B}(\mathrm{OH})_{4}{ }^{-} / \mathrm{HCO}_{3}{ }^{-}\right]_{\mathrm{sw}}$, the absolute values should be taken with caution. The trends recognized, however, because they are largely determined by $\mathrm{B} / \mathrm{Ca}$ can be considered robust.

Although the Miocene B/Ca record from ODP site 761 presented in this study encompasses the short-term variations in $\delta^{13} \mathrm{C}$ (i.e., $\mathrm{CM}$ events), due to the lack of complimentary $\delta^{11} \mathrm{~B}-\mathrm{pH}$ records at the same resolution, we are unable to estimate relative DIC on these timescales, based on records from this study (Supplementary Fig. 3). Here we look to the T. trilobus $\mathrm{B} / \mathrm{Ca}$ record from Malta which includes both $\mathrm{B} / \mathrm{Ca}$ and $\delta^{11} \mathrm{~B}-\mathrm{pH}$ estimates across $\mathrm{CM} 6$ and shows a similar increase in $\mathrm{B} / \mathrm{Ca}$ (Supplementary Fig. 3). Using the same approach as above and equations 4-7, we estimate relative change in DIC across CM6. A $17 \mu \mathrm{mol} / \mathrm{mol}$ increase in planktic B/ $\mathrm{Ca}$ and corresponding increase of $0.08 \mathrm{in} \mathrm{pH}$ (Supplementary Fig. 3 ) across the CM6 event equates to a lowering of DIC by $\sim 300 \mu \mathrm{mol} / \mathrm{kg}$, although in absolute terms this remains poorly constrained at present. We do note that to fully quantify and assess surface DIC changes on these timescales, a suite of orbitally resolved records of the carbonate system (i.e., $\mathrm{B} / \mathrm{Ca}$ and $\delta^{11} \mathrm{~B}$ ) across mid-Miocene carbon isotope excursions are needed.

\section{Data availability}

All data generated during this study supporting its findings are supplied in supplementary data files.

Received: 22 May 2019; Accepted: 15 November 2019; Published online: 09 January 2020

\section{References}

1. Walker, J. C. G., Hays, P. B. \& Kasting, J. F. A negative feedback mechanism for the long-term stabilization of earths surface-temperature. J. Geophys. Res. Oceans 86, 9776-9782 (1981).

2. Berner, R. A., Lasaga, A. C. \& Garrels, R. M. The carbonate-silicate geochemical cycle and its effect on atmospheric carbon-dioxide over the past 100 million years. Am. J. Sci. 283, 641-683 (1983).

3. Raymo, M. E. \& Ruddiman, W. F. Tectonic forcing of late cenozoic climate. Nature 359, 117-122 (1992).

4. Chamberlin, T. C. An attempt to frame a working hypothesis of the cause of glacial periods on an atmospheric basis. J. Geol. 7, 545-584 (1899).

5. Pagani, M., Caldeira, K., Berner, R. \& Beerling, D. J. The role of terrestrial plants in limiting atmospheric $\mathrm{CO} 2$ decline over the past 24 million years. Nature 460, 85-U94 (2009).

6. Raymo, M. E. The Himalayas, organic-carbon burial, and climate in the miocene. Paleoceanography 9, 399-404 (1994).

7. Derry, L. A. \& FranceLanord, C. Neogene growth of the sedimentary organic carbon reservoir. Paleoceanography 11, 267-275 (1996).

8. Rohling, E. J. et al. Making sense of palaeoclimate sensitivity. Nature 491, 683-691 (2012).

9. Gibbs, S. J. et al. Ocean warming, not acidification, controlled coccolithophore response during past greenhouse climate change. Geology 44, 59-62 (2016).

10. Martinez-Garcia, A. et al. Iron fertilization of the subantarctic ocean during the Last Ice Age. Science 343, 1347-1350 (2014).
11. Torres, M. A., Moosdorf, N., Hartmann, J., Adkins, J. F. \& West, A. J. Glacial weathering, sulfide oxidation, and global carbon cycle feedbacks. Proc. Natl Acad. Sci. USA 114, 8716-8721 (2017).

12. Hoenisch, B. et al. The geological record of ocean acidification. Science 335, 1058-1063 (2012)

13. Heinze, C. et al. Climate feedbacks in the Earth system and prospects for their evaluation. Earth Syst. Dynam. Discuss 540, 104-108 (2018).

14. Holbourn, A., Kuhnt, W., Simo, J. A. \& Li, Q. Y. Middle miocene isotope stratigraphy and paleoceanographic evolution of the northwest and southwest Australian margins (Wombat Plateau and Great Australian Bight). Palaeogeogr. Palaeoclimatol. Palaeoecol. 208, 1-22 (2004).

15. Levy, R. et al. Antarctic ice sheet sensitivity to atmospheric $\mathrm{CO}_{2}$ variations in the early to mid-Miocene. Proc. Natl Acad. Sci. USA 113, 3453-3458 (2016).

16. Woodruff, F. \& Savin, S. M. Delta-C-13 values of miocene pacific benthic foraminifera - correlations with sea-level and biological productivity. Geology 13, 119-122 (1985).

17. Holbourn, A., Kuhnt, W., Schulz, M., Flores, J. A. \& Andersen, N. Orbitallypaced climate evolution during the middle Miocene "Monterey" carbonisotope excursion. Earth Planet. Sci. Lett. 261, 534-550 (2007).

18. Savin, S. M. et al. The evolution of miocene surface and near-surface marine temperatures - oxygen isotopic evidence. Geol. Soc. Am. Mem. 163, 49-82 (1985).

19. Vincent, E., Killingley, J. S. \& Berger, W. H. Miocene oxygen and carbon isotope stratigraphy of the tropical indian-ocean. Geol. Soc. Am. Mem. 163, 103-130 (1985).

20. Woodruff, F. \& Savin, S. M. Mid-miocene isotope stratigraphy in the deep sea high-resolution correlations, paleoclimatic cycles, and sediment preservation. Paleoceanography 6, 755-806 (1991).

21. Lear, C. H., Mawbey, E. M. \& Rosenthal, Y. Cenozoic benthic foraminiferal $\mathrm{Mg} / \mathrm{Ca}$ and $\mathrm{Li} / \mathrm{Ca}$ records: toward unlocking temperatures and saturation states. Paleoceanography 25, https://doi.org/10.1029/2009pa001880 (2010).

22. Lewis, A. R., Marchant, D. R., Ashworth, A. C., Hemming, S. R. \& Machlus, M. L. Major middle Miocene global climate change: evidence from East Antarctica and the Transantarctic Mountains. Geol. Soc. Am. Bull. 119, 1449-1461 (2007).

23. Badger, M. P. S. et al. $\mathrm{CO}_{2}$ drawdown following the middle Miocene expansion of the Antarctic Ice Sheet. Paleoceanography 28, https://doi.org/ 10.1002/palo.20015 (2013)

24. Hodell, D. A. \& Woodruff, F. Variations in the strontium isotopic ratio of seawater during the miocene - stratigraphic and geochemical implications. Paleoceanography 9, 405-426 (1994).

25. Armstrong McKay, D. I., Tyrrell, T., Wilson, P. A. \& Foster, G. L. Estimating the impact of the cryptic degassing of Large Igneous Provinces: a midMiocene case-study. Earth Planet. Sci. Lett. 403, 254-262 (2014).

26. Pagani, M., Arthur, M. A. \& Freeman, K. H. Miocene evolution of atmospheric carbon dioxide. Paleoceanography 14, 273-292 (1999).

27. Loutit, T. S., Pisias, N. G. \& Kennett, J. P. Pacific miocene carbon isotope stratigraphy using benthic foraminifera. Earth Planet. Sci. Lett. 66, 48-62 (1983).

28. Zhang, Y. G., Pagani, M. \& Liu, Z. A 12-million-year temperature history of the tropical Pacific Ocean. Science 344, 84-87 (2014).

29. Foster, G. L., Lear, C. H. \& Rae, J. W. B. The evolution of $\mathrm{pCO}_{2}$, ice volume and climate during the middle Miocene. Earth Planet. Sci. Lett. 341, 243-254 (2012).

30. Greenop, R., Foster, G. L., Wilson, P. A. \& Lear, C. H. Middle Miocene climate instability associated with high-amplitude $\mathrm{CO}_{2}$ variability. Paleoceanography 29, 845-853 (2014)

31. Kasbohm, J. \& Schoene, B. Rapid eruption of the Columbia River flood basalt and correlation with the mid-Miocene climate optimum. Sci. Adv. 4, https:// doi.org/10.1126/sciadv.aat8223 (2018).

32. Kuerschner, W. M., Kvacek, Z. \& Dilcher, D. L. The impact of Miocene atmospheric carbon dioxide fluctuations on climate and the evolution of terrestrial ecosystems. Proc. Natl Acad. Sci. USA 105, 449-453 (2008).

33. Jenkyns, H. C. Geochemistry of oceanic anoxic events. Geochem. Geophys. Geosyst. 11, https://doi.org/10.1029/2009gc002788 (2010).

34. Holbourn, A., Kuhnt, W., Kochhann, K. G. D., Andersen, N. \& Meier, K. J. S Global perturbation of the carbon cycle at the onset of the Miocene Climatic Optimum. Geology 43, 123-126 (2015).

35. Sosdian, S. M. et al. Constraining the evolution of Neogene ocean carbonate chemistry using the boron isotope $\mathrm{pH}$ proxy. Earth Planet. Sci. Lett. 498, 362-376 (2018).

36. Abels, H. A. et al. Long-period orbital control on middle Miocene global cooling: integrated stratigraphy and astronomical tuning of the Blue Clay Formation on Malta. Paleoceanography 20, https://doi.org/10.1029/ 2004pa001129 (2005)

37. Zeebe, R. \& Wolf-Gladrow. $\mathrm{CO}_{2}$ in Seawater: Equilibrium, Kinetics, Isotopes. (2001).

38. Super, J. R. et al. North Atlantic temperature and $\mathrm{pCO}_{2}$ coupling in the earlymiddle Miocene. Geology 46, 519-522 (2018). 
39. Retallack, G. J. Refining a pedogenic-carbonate $\mathrm{CO}_{2}$ paleobarometer to quantify a middle Miocene greenhouse spike. Palaeogeogr. Palaeoclimatol. Palaeoecol. 281, 57-65 (2009).

40. John, C. M. et al. Timing and magnitude of Miocene eustasy derived from the mixed siliciclastic-carbonate stratigraphic record of the northeastern Australian margin. Earth Planet. Sci. Lett. 304, 455-467 (2011)

41. Shevenell, A. E., Kennett, J. P. \& Lea, D. W. Middle Miocene ice sheet dynamics, deep-sea temperatures, and carbon cycling: a Southern Ocean perspective. Geochem. Geophys. Geosyst. 9, https://doi.org/10.1029/ $2007 \mathrm{gc001736}$ (2008)

42. Gasson, E., DeConto, R. M., Pollard, D. \& Levy, R. H. Dynamic Antarctic ice sheet during the early to mid-Miocene. Proc. Natl Acad. Sci. USA 113, 3459-3464 (2016).

43. Simpson, J. H. \& Sharples, J. An Introduction to the Physical and Biological Oceanography of Shelf Seas (Cambridge Univ. Press, 2012).

44. FranceLanord, C. \& Derry, L. A. Organic carbon burial forcing of the carbon cycle from Himalayan erosion. Nature 390, 65-67 (1997).

45. Diester-Haass, L. et al. Mid-Miocene paleoproductivity in the Atlantic Ocean and implications for the global carbon cycle. Paleoceanography 24, https://doi. org/10.1029/2008pa001605 (2009).

46. Opdyke, B. N. \& Walker, J. C. G. Return of the coral-reef hypothesis - basin to shelf partitioning of caco3 and its effect on atmospheric $\mathrm{CO}_{2}$. Geology 20, 733-736 (1992).

47. Follmi, K. B. et al. Phosphogenesis and organic-carbon preservation in the miocene monterey formation at Naples beach, California - the monterey hypothesis revisited. Geol. Soc. Am. Bull. 117, 589-619 (2005).

48. Lauretano, V., Zachos, J. C. \& Lourens, L. J. Orbitally paced carbon and deepsea temperature changes at the peaK of the early Eocene Climatic Optimum. Paleoceanogr. Paleoclimatol. 33, 1050-1065 (2018).

49. Gutjahr, M. et al. Very large release of mostly volcanic carbon during the Palaeocene-Eocene Thermal Maximum. Nature 548, 573-577 (2017).

50. Miller, K. G. et al. The phanerozoic record of global sea-level change. Science 310, 1293-1298 (2005).

51. O'Brien, C. L. et al. Cretaceous sea-surface temperature evolution: constraints from $\mathrm{TEX}_{86}$ and planktonic foraminiferal oxygen isotopes. Earth Sci. Rev. 172, 224-247 (2017).

52. Flower, B. P. \& Kennett, J. P. M iddle miocene ocean-climate transition - highresolution oxygen and carbon isotopic records from Deep Sea Drilling Project site 588A, southwest pacific. Paleoceanography 8, 811-843 (1993).

53. Diester-Haass, L. et al. Paleoproductivity during the middle Miocene carbon isotope events: a data-model approach. Paleoceanography 28, 334-346 (2013).

54. Holbourn, A. et al. Middle Miocene climate cooling linked to intensification of eastern equatorial Pacific upwelling. Geology 42, 19-22 (2014).

55. Lear, C. H. et al. Neogene ice volume and ocean temperatures: Insights from infaunal foraminiferal $\mathrm{Mg} / \mathrm{Ca}$ paleothermometry. Paleoceanography 30, 1437-1454 (2015).

56. Mawbey, E. M. \& Lear, C. H. Carbon cycle feedbacks during the OligoceneMiocene transient glaciation. Geology 41, 963-966 (2013).

57. Palike, H. et al. The heartbeat of the oligocene climate system. Science 314, 1894-1898 (2006).

58. Ma, W. T., Tian, J., Li, Q. Y. \& Wang, P. X. Simulation of long eccentricity (400-kyr) cycle in ocean carbon reservoir during Miocene Climate Optimum: weathering and nutrient response to orbital change. Geophys. Res. Lett. 38, https://doi.org/10.1029/2011gl047680 (2011).

59. Party, S. S. Site 926 pp. 153-232 (Ocean Drilling Program, College Station, TX, 1995).

60. Pearson, P. N. Planktonic foraminifer biostratigraphy and the development of pelagic caps on guyots in the Marshall Islands group. Proc. Ocean Drill. Program Sci. Results 144, 21-59 (1995).

61. Tripati, A. K., Roberts, C. D. \& Eagle, R. A. Coupling of $\mathrm{CO}_{2}$ and Ice Sheet Stability Over Major Climate Transitions of the Last 20 Million Years. Science 326, 1394-1397 (2009).

62. Kennett, J. P. \& Srinavasan, M. S. Neogene Planktonic Foramifera: a phylogenetic atlas (Hutchinson Ross Publishing Company, Stroudsburg, PA, 1983).

63. Spezzaferri, S. et al. Fossil and genetic evidence for the polyphyletic nature of the planktonic foraminifera "Globigerinoides", and description of the new genus Trilobatus. PLoS ONE 10, https://doi.org/10.1371/journal.pone.0128108 (2015).

64. Seki, O. et al. Alkenone and boron-based Pliocene $\mathrm{pCO}_{2}$ records. Earth Planet. Sci. Lett. 292, 201-211, https://doi.org/10.1016/j.epsl.2010.01.037 (2010).

65. Anand, P., Elderfield, H. \& Conte, M. H. Calibration of Mg/Ca thermometry in planktonic foraminifera from a sediment trap time series. Paleoceanography 18, https://doi.org/10.1029/2002kpa000846 (2003).

66. Greenop, R. et al. A record of Neogene seawater delta B-11 reconstructed from paired delta B-11 analyses on benthic and planktic foraminifera. Climate 13, 149-170 (2017).

67. Pearson, P. N. \& Palmer, M. R. Atmospheric carbon dioxide concentrations over the past 60 million years. Nature 406, 695-699 (2000).
68. Barker, S., Greaves, M. \& Elderfield, H. A study of cleaning procedures used for foraminiferal $\mathrm{Mg} / \mathrm{Ca}$ paleothermometry. Geochem. Geophys. Geosyst. 4, https://doi.org/10.1029/2003gc000559 (2003).

69. Yu, J. M., Elderfield, H. \& Honisch, B. B/Ca in planktonic foraminifera as a proxy for surface seawater $\mathrm{pH}$. Paleoceanography 22, https://doi.org/10.1029/ 2006 pa001347 (2007).

70. Lear, C. H., Rosenthal, Y. \& Slowey, N. Benthic foraminiferal Mg/Capaleothermometry: a revised core-top calibration. Geochimica Et. Cosmochimica Acta 66, 3375-3387 (2002).

71. Henehan, M. J. et al. Evaluating the utility of $\mathrm{B} / \mathrm{Ca}$ ratios in planktic foraminifera as a proxy for the carbonate system: a case study of Globigerinoides ruber. Geochem. Geophys. Geosyst. 16, 1052-1069 (2015).

72. Klinkhammer, G. P., Mix, A. C. \& Haley, B. A. Increased dissolved terrestrial input to the coastal ocean during the last deglaciation. Geochem. Geophys. Geosyst. 10, https://doi.org/10.1029/2008gc002219 (2009).

73. Hasiuk, F. J. \& Lohmann, K. C. Application of calcite Mg partitioning functions to the reconstruction of paleocean $\mathrm{Mg} / \mathrm{Ca}$. Geochim. Cosmochim Acta 74, 6751-6763 (2010).

74. Horita, J., Zimmermann, H. \& Holland, H. D. Chemical evolution of seawater during the Phanerozoic: implications from the record of marine evaporites. Geochim. Cosmochim. Acta 66, 3733-3756 (2002).

75. Evans, D. \& Mueller, W. Deep time foraminifera $\mathrm{Mg} / \mathrm{Ca}$ paleothermometry: nonlinear correction for secular change in seawater Mg/Ca. Paleoceanography 27, https://doi.org/10.1029/2012pa002315 (2012).

76. Delaney, M. L., Be, A. W. H. \& Boyle, E. A. LI, SR, MG, and NA in foraminiferal calcite shells from laboratory culture, sediment traps, and sediment cores. Geochim. Cosmochim. Acta 49, 1327-1341 (1985).

77. Gray, W. R. \& Evans, D. Nonthermal influences on $\mathrm{Mg} / \mathrm{Ca}$ in planktonic foraminifera: a review of culture studies and application to the Last Glacial Maximum. Paleoceanogr. Paleoclimatol. 34, 306-315 (2019).

78. Key, R. M. et al. A global ocean carbon climatology: results from Global Data Analysis Project (GLODAP). Global Biogeochem. Cycles 18, https://doi.org/ 10.1029/2004gb002247 (2004).

79. Sexton, P. F., Wilson, P. A. \& Pearson, P. N. Microstructural and geochemical perspectives on planktic foraminiferal preservation: "Glassy" versus "Frosty". Geochem. Geophys. Geosyst. 7, https://doi.org/10.1029/2006gc001291 (2006).

80. Edgar, K. M., Anagnostou, E., Pearson, P. N. \& Foster, G. L. Assessing the impact of diagenesis on delta B-11, delta C-13, delta O-18, Sr/Ca and B/Ca values in fossil planktic foraminiferal calcite. Geochim. Cosmochim. Acta 166, 189-209 (2015).

81. Allen, K. A., Honisch, B., Eggins, S. M. \& Rosenthal, Y. Environmental controls on $\mathrm{B} / \mathrm{Ca}$ in calcite tests of the tropical planktic foraminifer species Globigerinoides ruber and Globigerinoides sacculifer. Earth Planet. Sci. Lett. 351, 270-280 (2012).

82. Hemming, N. G. \& Hanson, G. N. Boron isotopic composition and concentration in modern marine carbonates. Geochim. Cosmochim. Acta 56, 537-543 (1992).

83. Howes, E. L. et al. Decoupled carbonate chemistry controls on the incorporation of boron into Orbulina universa. Biogeosciences 14, 415-430 (2017).

84. Haynes, L. L. et al. Calibration of the B/Ca proxy in the planktic foraminifer Orbulina universa to Paleocene seawater conditions. Paleoceanography 32, 580-599 (2017).

85. Babila, T. L. et al. Capturing the global signature of surface ocean acidification during the Palaeocene-Eocene Thermal Maximum. Philosophical Transactions of the Royal Society A: Mathematical, Physical and Engineering Sciences 376.2130, 20170072 (2018).

86. Foster, G. L. Seawater $\mathrm{pH},{ }_{\mathrm{P}} \mathrm{CO}_{2}$ and $\mathrm{CO}_{3}{ }^{2-}$ variations in the Caribbean Sea over the last $130 \mathrm{kyr}$ : A boron isotope and $\mathrm{B} / \mathrm{Ca}$ study of planktic forminifera. Earth Planet. Sci. Lett. 271, 254-266 (2008).

87. Ni, Y. Y. et al. A core top assessment of proxies for the ocean carbonate system in surface-dwelling foraminifers. Paleoceanography 22, https://doi.org/ 10.1029/2006pa001337 (2007).

88. Lemarchand, D., Gaillardet, J., Lewin, E. \& Allegre, C. J. Boron isotope systematics in large rivers: implications for the marine boron budget and paleo-pH reconstruction over the Cenozoic. Chem. Geol. 190, 123-140 (2002).

89. Hain, M. P., Sigman, D. M., Higgins, J. A. \& Haug, G. H. The effects of secular calcium and magnesium concentration changes on the thermodynamics of seawater acid/base chemistry: Implications for Eocene and Cretaceous ocean carbon chemistry and buffering. Glob. Biogeochem. Cycles 29, 517-533 (2015).

90. Ridgwell, A. A mid Mesozoic revolution in the regulation of ocean chemistry. Mar. Geol. 217, 339-357 (2005).

91. Boudreau, B. P., Middelburg, J. J., Sluijs, A. \& van der Ploeg, R. Secular variations in the carbonate chemistry of the oceans over the Cenozoic. Earth Planet. Sci. Lett. 512, 194-206 (2019).

92. Raitzsch, M. \& Honisch, B. Cenozoic boron isotope variations in benthic foraminifers. Geology 41, 591-594 (2013). 
93. Hooper, P. R., Binger, G. B. \& Lees, K. R. Ages of the Steens and Columbia River flood basalts and their relationship to extension-related calc-alkalic volcanism in eastern Oregon. Geol. Soc. Am. Bull. 114, 43-50 (2002).

94. Barron, J. A. in Siliceous Microfossil and Microplankton of the Monterey Formation and Modern Analogs 105-120 (Pacific Section SEPM, 1986).

95. Holdgate, G. R. et al. The middle Miocene Yallourn coal seam - the last coal in Australia the last. Int. J. Coal Geol. 70, 95-115 (2007).

\section{Acknowledgements}

This work was funded by NERC Grant NE/I006427/1 to C.H.L. and G.L.F. S.M.S acknowledges the financial support provided by the Welsh Government and Higher Education Funding Council for Wales through the Ser Cymru National Research Network for Low Carbon, Energy, and Environment Returning Fellowship. We thank Anabel Morte-Rodenas for lab assistance and Paul Pearson for providing samples from ODP 872 and assistance with taxonomy.

\section{Author contributions}

S.M.S., T.L.B. and C.H.L. designed and developed this study using boron-based proxies in planktic foraminifera across the Neogene. R.G. provided support on data interpretation and G.L.F. provided valuable insight on carbon cycle estimates and interpretation of B/Ca proxy. S.M.S., T.L.B. and C.H.L. wrote the manuscript with valuable contributions from all other authors.

\section{Competing interests}

The authors declare no competing interests.

\section{Additional information}

Supplementary information is available for this paper at https://doi.org/10.1038/s41467019-13792-0.

Correspondence and requests for materials should be addressed to S.M.S.

Peer review information Nature Communications thanks Cédric John and Chiara Borrelli for their contribution to the peer review of this work.

Reprints and permission information is available at http://www.nature.com/reprints

Publisher's note Springer Nature remains neutral with regard to jurisdictional claims in published maps and institutional affiliations.

(c) (i) Open Access This article is licensed under a Creative Common Attribution 4.0 International License, which permits use, sharing, adaptation, distribution and reproduction in any medium or format, as long as you give appropriate credit to the original author(s) and the source, provide a link to the Creative Commons license, and indicate if changes were made. The images or other third party material in this article are included in the article's Creative Commons license, unless indicated otherwise in a credit line to the material. If material is not included in the article's Creative Commons license and your intended use is not permitted by statutory regulation or exceeds the permitted use, you will need to obtain permission directly from the copyright holder. To view a copy of this license, visit http://creativecommons.org/ licenses/by/4.0/.

(C) The Author(s) 2020 